\title{
Atmospheric Response to the Sea Surface Temperature Anomalies Observed in Early Summer of 1983
}

- A Numerical Experiment--

\author{
By Tatsushi Tokioka, Koji Yamazaki and Masaru Chiba \\ Meteorological Research Institute, Tsukuba, Ibaraki, 305, JAPAN \\ (Manuscript received 15 April 1985, in revised form 7 June 1985)
}

\begin{abstract}
Atmospheric response to the observed sea surface temperature anomaly (SSTA) over the Pacific and Atlantic Oceans is studied with the use of the MRI (Meteorological Research Institute) $\cdot G C M$ for the period from May to June of 1983. El Niño event was still active during the period. The model is the tropospheric five layer grid model of which horizontal resolution is $5^{\circ}$ in longitude and $4^{\circ}$ in latitude.

Two groups of run are performed, one with the observed SST in 1983 (abbreviated as "R"), and the other with the climatological SST (abbreviated as " $N$ "). Each group consists of five runs among which the initial time varies from $00 \mathrm{Z} 1$ May to $00 \mathrm{Z} 3$ May with a half day interval. Atmospheric response to the SSTA is studied by comparing the results of "R" and " $N$ ".

The monthly mean differences between " $R$ " and " $N$ " are statistically significant and the basic feature of the response is similar to that of previous studies. The "Walker circulation" is diminished in " $R$ ". The reduction of precipitation occurs over the Indian Ocean. Anomalous anti-cyclonic pair straddles the equator in the upper troposphere and subtropical jets are intensified. In middle-latitudes, larger responses are obtained in the southern hemisphere. In the northern hemisphere a PNA-like pattern appears, shifted eastward from the location in winter.

Initial development of atmospheric anomalies is also studied. Westward traveling Rossby and eastward traveling Kelvin wave responses are dominated in the tropics. The Rossby wave train emanating from the eastern equatorial Pacific is clearly detected in the middlelatitudes.
\end{abstract}

\section{Introduction}

An importance of equatorial sea surface temperature (SST) not only to the tropical atmospheric circulation but also to the midlatitudes has been widely recognized from both the observational and theoretical studies. In particular, prolonged warm SST episodes over the central and eastern equatorial Pacific, known as El Niño event, have large effects upon the tropical atmospheric circulation through the enhanced condensation heating over the warm SST anomaly (SSTA) region. The climatological life cycle of El Niño event is documented by Rasmusson and Carpenter (1982). The El Niño event is closely related with the planetary-scale pressure seesaw between the equatorial eastern Pacific and the Indian Ocean, known as the Southern Oscillation. The $\mathrm{El} \mathrm{Niño/Southern} \mathrm{Oscillation}$ (ENSO) is the main agent that gives rise to the interannual variability in the tropics. The atmospheric response to the localized heating placed in the tropics has been studied theoretically by Matsuno (1966), Gill (1980), Webster (1981) etc. and their results accord with the observation (see e.g., Horel and Wallace, 1981). Furthermore theoretical studies show 
that the large heating over the tropical SSTA can affect the extratropical atmospheric circulation when the basic flow is suitable for the propagation of the quasi-barotropic Rossby wave (see e.g., Hoskins and Karoly, 1981; Gill, 1980).

General circulation model (GCM) experiments have been conducted to assess the effects of the SSTA over the equatorial Pacific. Rowntree (1972) performed the first experiment on this theme with a hemispheric model and confirmed Bjerknes' $(1966,1969)$ hypothesis. Julian and Chervin (1978) also performed sensitivity experiments to the SSTAs with a global model and estimated the statistical significance of the results. In 1980's, the study on this theme has revived, neatly aided with the clarification of observational relationships between El Niño and abnormal climate in the extratropics (Horel and Wallace, 1981) and partly aided with the appearance of ray path theory of Rossby waves (Hoskins and Karoly, 1981) as a new theoretical background to explain teleconnection mechanisms between the tropics and the extratropics. Shukla and Wallace (1983), Blackmon et al. (1983) and Tokioka et ai. (1985) have performed simulations of the atmospheric response to the $\mathrm{El}$ Niño event under the winter condition of the northern hemisphere. Keshavamurty (1982) studied characteristics of atmospheric response to the idealized equatorial Pacific SSTA under the summer condition.

All of the sensitivty experiments mentioned above used either idealized or climatological local SSTA. In the present study, we intend to use the SSTA observed in the early summer of 1983 and to see how the atmosphere responds to the SSTA. Most of the previous GCM experiments were performed under northern winter condition probably because a large extratropical response to the tropical SSTA has been revealed so far in winter of the northern hemisphere. One reason for our choosing early summer season is that sensitivity experiments under different seasonal conditions will improve our understanding of the response. The other reason is that the intense $1982 / 83 \mathrm{El}$ Niño event lasted longer than usual and the SSTA over the eastern equatorial Pacific was exceptionally strong during spring and early summer of 1983. This gives us a good case for investigation. The atmospheric initial condition used in this study is also the observed one and the model was integrated for 2 months with and without the SSTA. Hence, we can verify the results of the experiment against the real observation. One intriguing problem which can be explored by our experiment is how the numerical weather forecasting of monthly means is affected by using observed SSTAs, instead of climatological ones. This subject will be discussed in the forthcoming paper. Therefore the comparison of the results with the observational data will be lightly touched in this paper and the emphasis is placed on the atmospheric response to the SSTA.

Section 2 of this paper describes the experimental design. In the GCM experiments on SSTA presented so far, initial development of atmospheric anomalies has not been discussed in detail. Here we intend to clarify how atmospheric anomalies establish after the insertion of SSTA. Section 3 is devoted for this end. Section 4 describes the time-averaged response in the tropics, while Section 5 mainly describes the extratropical response. Section 6 summarizes the results with discussions.

\section{Experimental design}

\subsection{Model}

The model used in the present study was. developed at the Meteorological Research Institute (MRI) and is comprehensively described by Tokioka et al. (1984). The model (MRI. GCM-I) is basically identical to the UCLA (University of Calfornia, Los Angeles) model described by Arakawa and Mintz (1974) and Arakawa and Lamb (1977), with minor changes to both the dynamical and physical processes of the model. The January performance of the MRI.GCM-I is reported by Tokioka et al. (1985) and the July performance is reported by Kitoh and Tokioka (1985).

The model employs finite difference approximations to the governing equations in both horizontal and vertical directions. In the 
vertical the model uses a modified sigmacoordinate, i.e., $\sigma=\left(p-p_{t}\right) /\left(p_{s}-p_{t}\right)$, where $p$ is pressure, $p_{t}$ is pressure at the top of the model $\left(=100 \mathrm{mb}\right.$ ), and $p_{s}$ is surface pressure. There are five layers in the vertical with layer interfaces located at $1 / 9,3 / 9,5 / 9,7 / 9$ in $\sigma$. The Arakawa $C$ grid scheme is used with a horizontal resolution of $5^{\circ}$ in the zonal direction and $4^{\circ}$ in the meridional direction. The time differencing used in the model for the basic dynamical terms is the leapfrog scheme with a periodical insertion of the Matsuno scheme.

Solar and terrestrial radiative heating rates are computed following the formulation of Katayama (1972) as described by Tokioka et al. (1984). The seasonal and diurnal variations of solar insolation are prescribed at the top of the atmosphere. Hence, the model undergoes the diurnal cycle as well as the seasonal cycle. The radiative heating rates are computed by considering clouds, water vapor and carbon dioxide. Predicted amounts of water vapor and cloud are used for the calculation.

The dry convective adjustment, middle level convection and penetrative cumulus parameterization of Arakawa and Schubert (1974) are used for parameterizing the convective processes.

Planetary boundary layer (PBL) is modeled with the parameterization proposed by Randall (1976) with some modifications. The model predicts the PBL depth, the gaps of temperature, moisture and wind at the top of the PBL. Surface fluxes of sensible heat, moisture and momentum are computed by the bulk method with the transfer coefficient proposed by Deardorff (1972).

Ground temperature and snow mass are predicted by considering ground thermodynamics and hydrology. Unlike the standard MRI.GCM-I, however, ground wetness and surface albedo are prescribed in the present model. This modification was introduced because the standard model showed too much sensitivity to the ground condition in the preliminary study. The adopted data are the same as those used in Suarez et al. (1983). The surface albedo is taken from Posey and
Clapp (1964) and the ground wetness from Mintz (personal communication). Ocean surface temperatures are prescribed and updated once a day with a cubic spline interpolation from the monthly mean values.

\subsection{Experiment}

We have run ten experiments from the beginning of May to 1 July. Five of them used climatological SST as the surface boundary condition. These experiments will be hereafter referred to as "normal SST runs" (abbreviated as " $N$ "). The starting times for the five " $N$ " are 00Z 1 May, $12 Z 1$ May, 00Z 2 May, $12 Z 2$ May and 00Z 3 May of 1983, respectively. The initial data used in this study are taken from the global analysis at the Electronic Computation Center, Japan Meteorological Agency.

Other five experiments were integrated by using observed sea surface temperatures during the corresfonding months of 1983 . These experiments will be hereafter referred to as "real SST runs" (abbreviated as " $R$ "). The starting times and initial conditions for five " $R$ " are the same as for " $N$ ". Hence, " $R$ " differ from " $N$ " only with respect to the sea surface temperatures. The schematic illustration of the experiments is given in Fig. 1. An experiment with a single control run and anomaly run is not sufficient to estimate the statistical significance of response. For this kind of sensitivity experiment, perturbed runs are usually performed by adding small noises to both control and anomaly runs at the same initial time. Such perturbed runs are, however, dynamically inconsistent at the initial time. In this paper we adopted an alternative way mentioned above to obtain the ensemble mean. Five atmospheric states in each group on $00 \mathrm{Z} 3$ May are slightly different but dynamically consistent in our case.

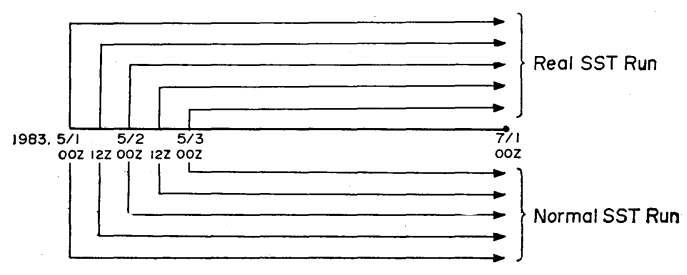

Fig. 1 Schematic illustration of the experiments. 

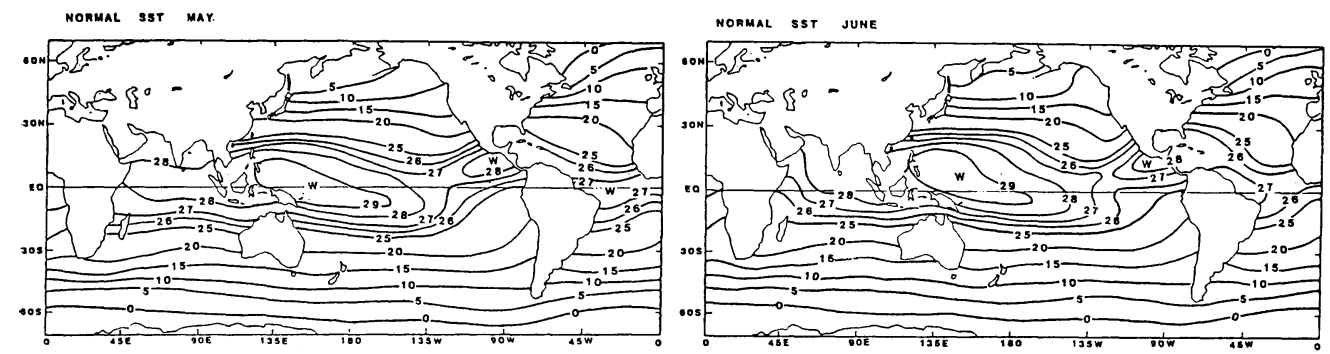

SST ANOMALY MAY (1083)

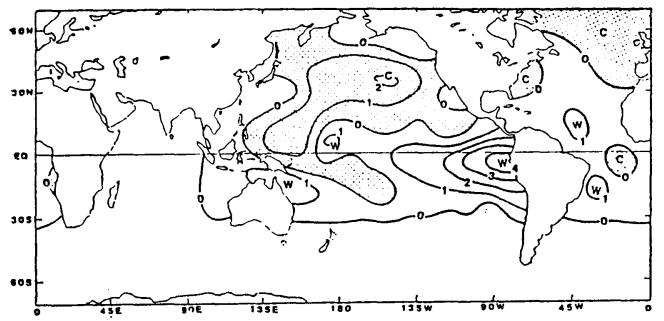

SST ANOMALY JUNE (1083)

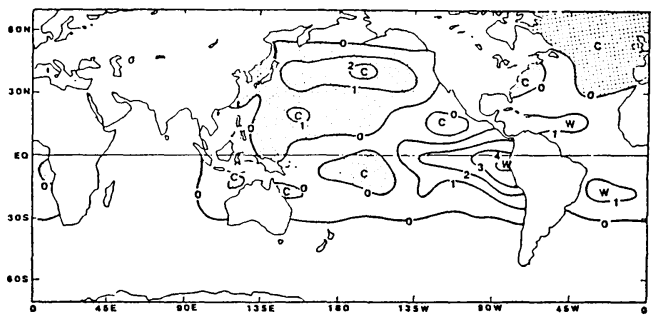

Fig. 2 Top: Normal SST fields taken from Alexander and Mobley (1976) for May (left) and June (right). This SST is used for " $N$ ". Bottom: SST anomaly field in 1983 for May (left) and June (right).

The climatological SSTs by Alaxander and Mobley (1976) and the monthly mean SSTAs observed in 1983 are shown in Fig. 2. The robust 1982-83 EI Niño event was still active during May and June, 1983. The development of this extraordinary episcde and the related anomalous circulation in the atmosphere are reported in Seasonal Climate Summaries in the Monthly Weather Review by many authors (Wagner, 1983; Krueger, 1983 ; Quiroz; 1983 ; Chen, 1983; Ropelewski, 1984). Large warm anomalies are seen in the eastern equatorial Pacific for both May and June; Peak values exceed $4^{\circ} \mathrm{K}$ off the Peru coast. In the central equatorial Pacific, warm anomalies are observed in May. However, the warm anomalies weaken in June. The SSTAs in Fig. 2 are different from the ones observed" during a mature phase of a typical El Niño event in their strength and pattern (Rasmusson and Carpenter, 1982; Philander, 1983). In the composite SSTA map by Rasmusson and Carpenter (1982), the center of warm SSTA appears near the dateline in the mature phase and the values are less than $2^{\circ} \mathrm{K}$. Whereas, the center of the warm SSTA is shifted eastward and the values are large during this season of 1983. It is intriguing to note that the Southern Oscillation Index (normalized
Tahiti-Darwin sea level pressure) showed near normal value during May and June, 1983 (Ropelews'ki, 1984).

Other warm SSTA are found over the equatorial Atlantic; Cold SSTAs are found in the north Pacific and the north Atlantic. No anomalies are given over the Indian Ocean and the Antarctic Ocean because data were not available.

\section{Short-time response}

The initial conditions of " $R$ " and " $N$ " are exactly the same except the prescribed sea surface temperatures. Therefore, the difference of the atmospheric circulation between " $R$ " and " $N$ " is small at the early stage of the integration. As shown in Fig. 1, we have five pairs of runs between " $R$ " and " $N$ ". Differences between two runs in each pair include those due to natural noise of the atmospheric flow as well as those forced by the SSTA. We may consider the differences as a function of time from the initial time of each pair, and take an average with respect to the time among five cases. Differences due to natural noise will decrease in the averaging process as natural noise may be considered random. If we consider further that the effects of the differences in the initial 

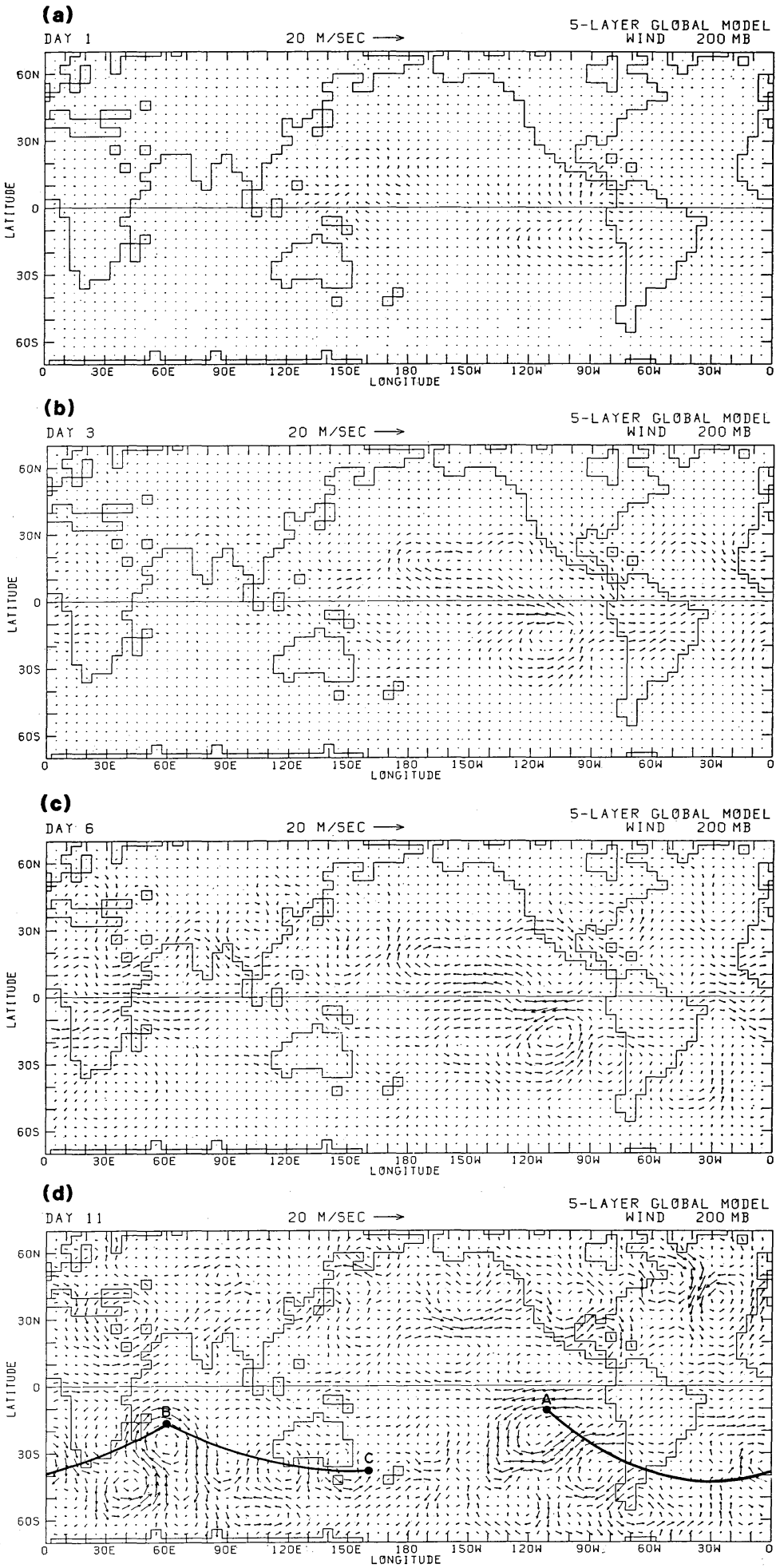

Fig. 3 The wind difference at $200 \mathrm{mb}$ between " $R$ " and " $N$ " for Day 1 (top), 3 (second), 6 (third) and 11 (bottom). A reference arrow is shown at the top of each panel. 
basic state are small in the present situation on the evolution of the atmospheric response to the SSTA, the mean differences that emerge after the averaging are considered to describe the propagation of atmospheric shock or the development of atmospheric anomalies induced by the SSTA.

Fig. 3 shows the mean differences in wind vector at $200 \mathrm{mb}$ between " $R$ " and " $N$ " for the day $1,3,6$ and 11 after the initial time. On the day 1 noticeable difference appear only in the eastern and western equatorial Pacific. On the day 3 an anticyclonic vortex pair straddles the equator over the eastern Pacific. Easterly anomalies are dominant on the western side of the warm SSTA center off the Peru coast. On the eastern side of it are formed dominant westerly anomalies. Lau and Lim (1982) studied the time evolution of the equatorial atmosphere to both the symmetric and anti-symmetric thermal forcings with the linear equatorial $\beta$-plane model. They showed that westward traveling Rossby and eastward traveling Kelvin waves are generated by the symmetric forcing. While, no Kelvin waves are excited by anti-symmetric forcing and the response consists of a local component plus a slowly westward traveling component. In the present study, we detect both westward traveling Rossby and eastward traveling Kelvin waves. The cyclonic vortex starts to form off the Chile coast. On the day 6 the vortex trains from the eastern equatorial Pacific are noticeable, in both hemispheres. The one in the southern hemisphere is directed southeastward, and is more dominant than that in the northern hemisphere. These votex trains are quasi-barotropic and the shape of the trains has a similarity to those predicted by the ray path theory of Rossby waves (Hoskins and Karoly, 1981). On the equator strong easterly anomalies are seen over the central and eastern Pacific and strong westerly anomalies in the area from the Atlantic to the Malay Peninsula. It is recognized that the phase speed of the westerly anomalies is much faster than that of the easterly anomalies. This is consistent with the fact that the absolute phase speed of Kelvin wave is faster than that of Rossby wave. Directions of wind anomalies at the lower troposphere are opposite to the one at the upper troposphere in the equatorial zone (Figures are not shown). On the day 11 the wind anomalies have spread over the entire sphere.

It may be reasonable to say that the response in the mid-latitudes is mainly caused by the propagation of Rossby wave from the equatorial warm SSTA region, although the given SSTA are nearly global and include large negative SSTA over the North Pacific as seen in Fig. 2. Such a different impact of SSTA on the atmosphere between the tropics and extratropics may be ascribed to the difference of dynamical response (Webster, 1981; Hoskins and Karoly, 1981). In the tropics, the response of the air column to the SSTA is fast through penetrative cumulus convection and easily bring about convergent/divergent fields and vertical motion over the SSTA. This divergent/convergent field, in turn, transports moisture into the warm SSTA region and intensify the heating. The heating is mainly balanced by the cooling due to upward motion. On the other hand, the motion in the extratropics is quasihorizontal due to Colioris effect. Therefore the heating is mainly balanced by the cooling due to horizontal advection and the positive feedback between the SSTA and dynamical effects acting in the tropics, does not work in the extratropics. The ray paths from the equatorial SSTA are important in transporting signals from the tropics to the mid-latitudes.

Generally, wind anomalies in the southern hemisphere are larger than the ones in the northern hemisphere. This feature can mainly be attributed to the zonal wind pattern (see Fig. 4). In the eastern equatorial Pacific the westerly wind extends close to the equator in the southern hemisphere. Therefore, the Rossby wave train originated in the tropics easily propagates into the extratropics of the southern hemisphere (see e.g., Lim and Chang, 1983; Lau and Lim, 1984).

Fig. 5 shows the vorticity difference along the path A-B-C in Fig. 3d. The ordinate is time in day. Although the path is chosen 


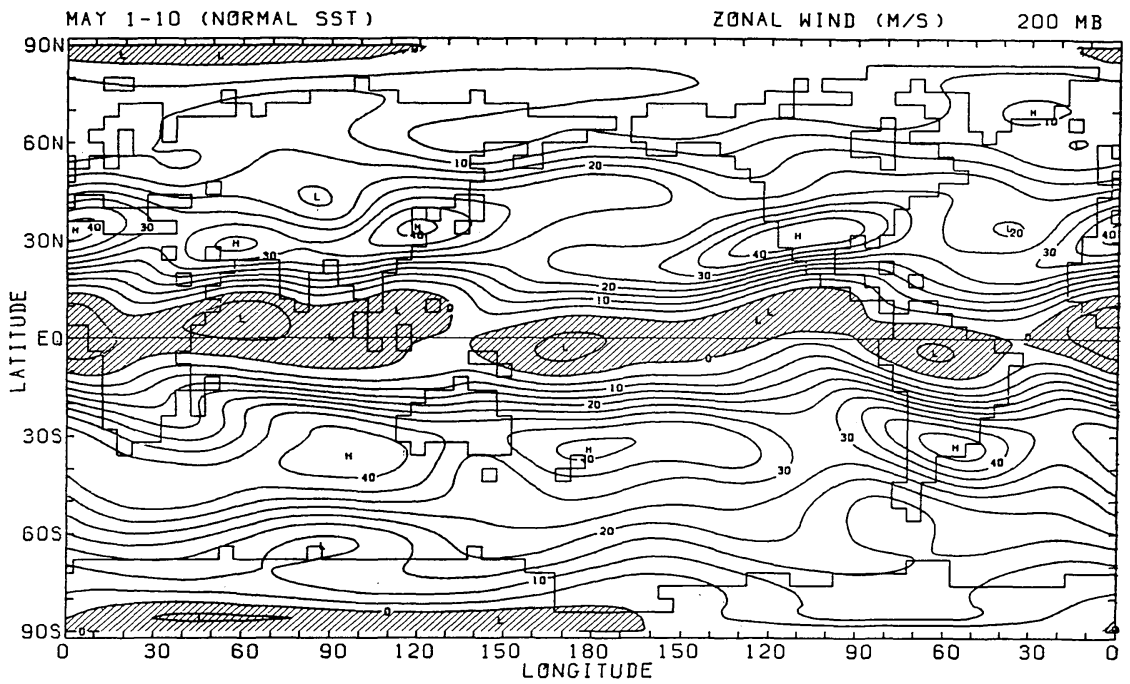

Fig. 4 Mean zonal wind at $200 \mathrm{mb}$ simulated by " $N$ " during May 1-10. Easterly regions are shaded. Contour interval is $5 \mathrm{~m} / \mathrm{s}$.

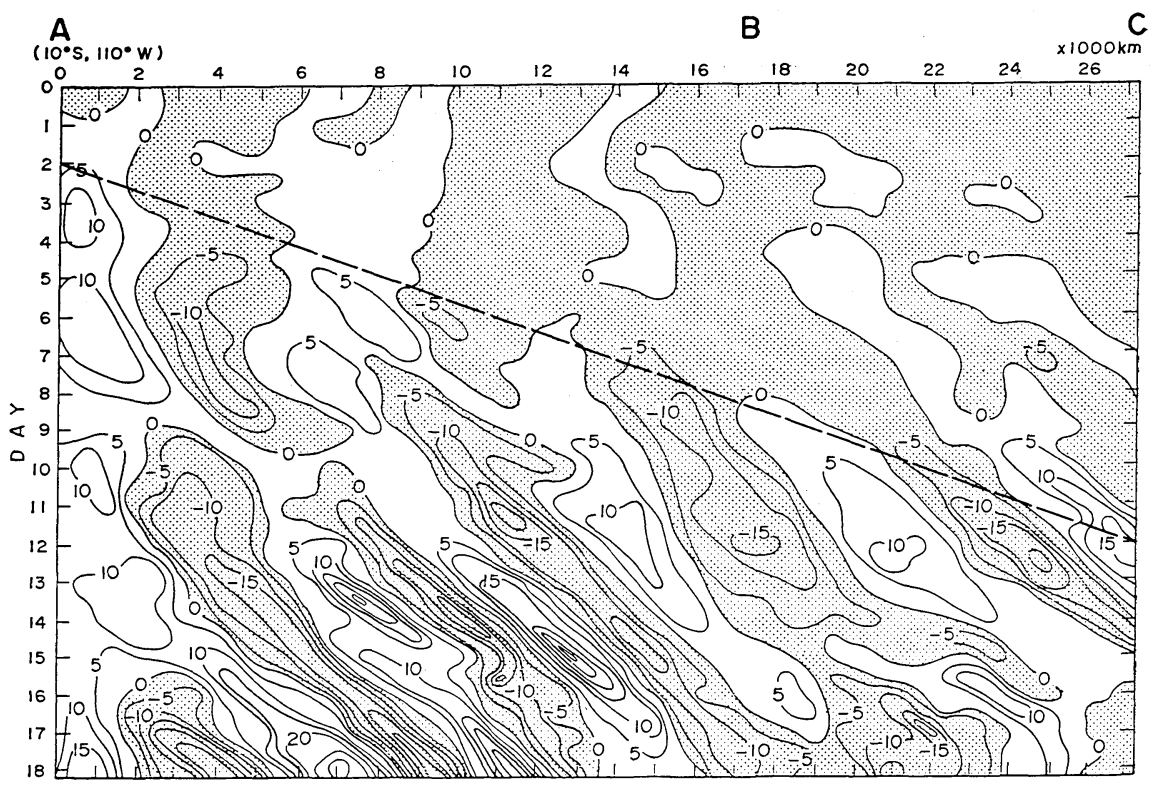

Fig. 5 The vorticity difference between " $R$ " and " $N$ " at $200 \mathrm{mb}$. The ordinate is the day from the initial time and the abscissa is the distance from the point A $\left(10^{\circ} \mathrm{S}, 110^{\circ} \mathrm{W}\right)$ along the path $\mathrm{A}-\mathrm{B}-\mathrm{C}$ shown in the bottom panel of Fig. 3. Negative regions are shaded. Contour interval is $5 \times 10^{-6} \mathrm{~s}^{-1}$.

subjectively from Figs. 3a-d, it is also close to a great circle, which is an exact ray path for the basic flow in solid rotation (Hoskirs and Karoly, 1981). We put a kink at point $\mathrm{B}$ to examine the possibility of Rossby wave reflection near the critical latitude as discussed by Branstator (1983) and Nigam and
Held (1983). Near the point A, the positive anomalies persist during the period. The large anomalies are established around the day 2 near the point A. After that, the front of anomalies seems to propagate along the path at a nearly steady speed. The dashed line in Fig. 5 indicates a lire of constant speed 
$2700 \mathrm{~km} /$ day along the path. While each anomaly seems to travel eastward along the path at much slower speed (about $800 \mathrm{~km} /$ day). The intensity at the point $A$ varies with time. The crests of the large anomalies starting on the day 5 and 9 from the point A also seem to propagate along the path at a similar speed. When the basic zonal mean flow is $10 \mathrm{~m} / \mathrm{s}$, the group velocity of a Rossby wave for the zonal wavenumber 5 and the meridional wave lenght of $10000 \mathrm{~km}$ is approximately $2400 \mathrm{~km} /$ day at $30^{\circ} \mathrm{S}$ and it is 3200 $\mathrm{km} /$ day when the baisic flow is $20 \mathrm{~m} / \mathrm{s}$. These values roughly agree with the value graphically estimated from Fig. 5. Therefore we can safely state that these anomalies propagated as the Rossby wave train. In addition, the first front of the anomalies can be traced uniformly up to the point $\mathrm{C}$ in Fig. 5. This feature does not contradict with the idea of reflection of Rossby waves at a cirtical latitude (Branstator, 1983; Nigam and Held, 1983). However, weak eddies had already been formed between $\mathrm{B}$ and $\mathrm{C}$ a few days before


Fig. 6 Top: The monthly mean precipitation difference between " $R$ " and " $N$ " for May. Negative regions are shaded. Contour interval is $1 \mathrm{~mm} /$ day. Bottom: Same as the top panel except for June. 
the first front reached there. The arrival of the reflected wave seems to have enhanced the eddies beyond $\mathrm{B}$ point. Morever the reflection is not clearly seen after the passage of the first front. The initial shock, i.e., the instantaneous large SST difference between " $R$ " and " $N$ ", is purely artificial and the same situation never occurs in nature. A caution may be needed when the idea of reflection of Rossby waves is applied to the observation.

\section{Tropical response}

In this section, the atmospheric response in the tropics to the SSTA is primarily ex- amined. In May, as is seen in Fig. 2, positive SSTA extends over the eastern equatorial Pacific. There is a separate peak of positive SSTA near the dateline. Negative SSTA is located around $145^{\circ} \mathrm{E}$. In June, negative SSTA is intensified around $150^{\circ} \mathrm{W}$ and a strong gradient in SSTA is formed around $135^{\circ} \mathrm{W}$. The positive peak near the dateline and also the negative SSTA to the west of that peak have decreased their intensity in this month.

Fig. 6 shows the monthly mean differences in precipitation between " $R$ " and " $N$ " and Fig. 7 those in evaporation. The most significant increases in both fields are found
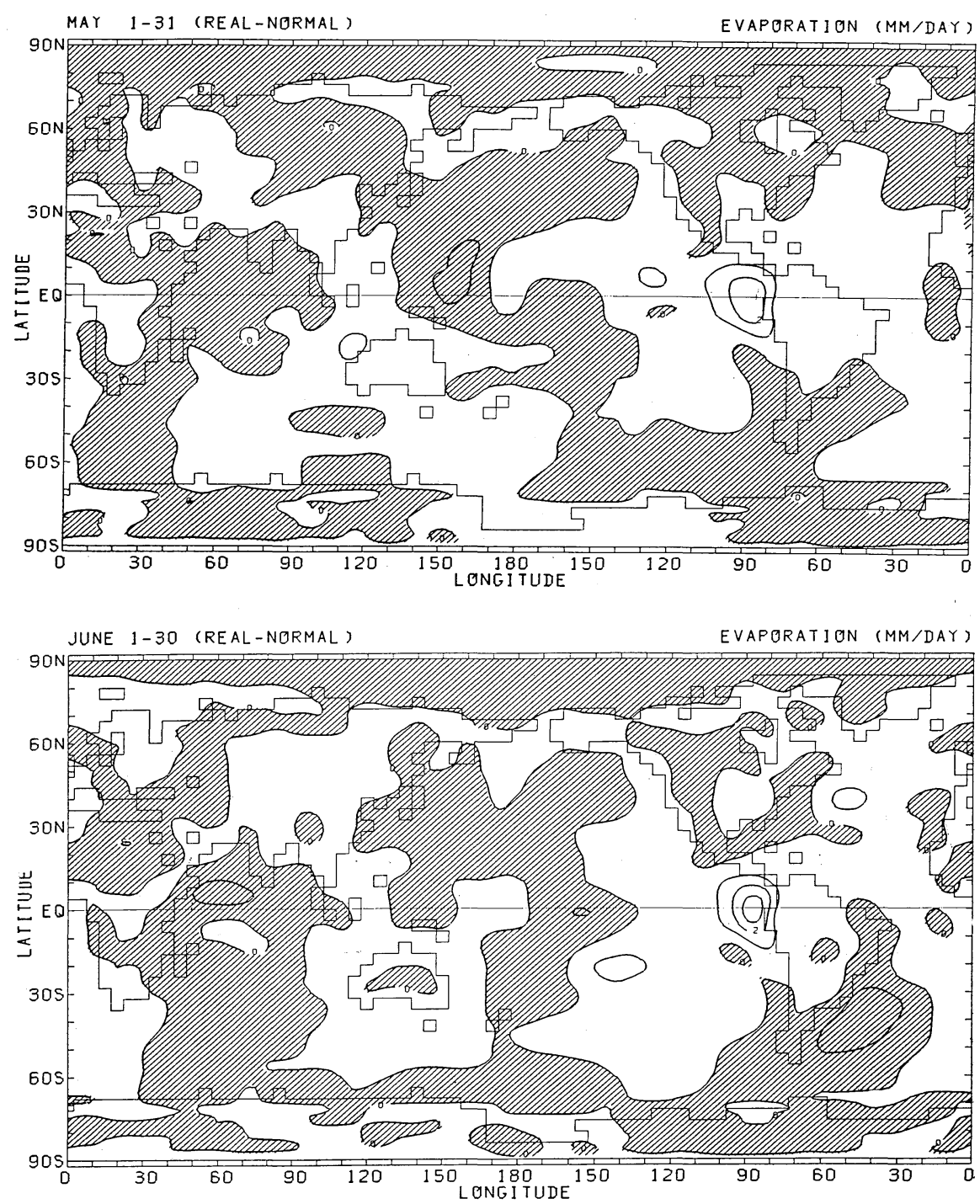

Fig. 7 Same as Fig. 6 except for evaportion. 
over the warm SSTA areas in the eastern equatorial Pacific in both May and June. Precipitation anomalies are much larger than the evaporation anomalies in those areas. This implies that the enhancement of precipitation over the warm SSTA is mainly supported by the dynamical effect, i.e., the convergence of moisture from the surrounding regions. Similar features are also found in other warm SSTA areas such as over the equatorial Atlantic and the Arafura Sea.

Marked decreases in both fields can be seen over the western equatorial Pacific in May and over the central equatorial Pacific in June. The marked decrease position from May to June seems to follow the changes in the negative SSTA areas between the two months. The normal SST is high over the western and the central equatorial Pacific. Hence even the small SSTA change in those areas may cause large heating difference as the saturated water vapor pressure increases rather exponentially with temperature. This may partially explain the marked decreases in both precipitation and evaporation. Moreover, an induced descending motion in close western vicinity of the dominant positive SSTA helps to suppress precipitation further. Keshavamurty (1982) showed that a large decrease of precipitation occurs to the west of warm SSTA in his numerical experiment though a negative SSTA is not specified there.
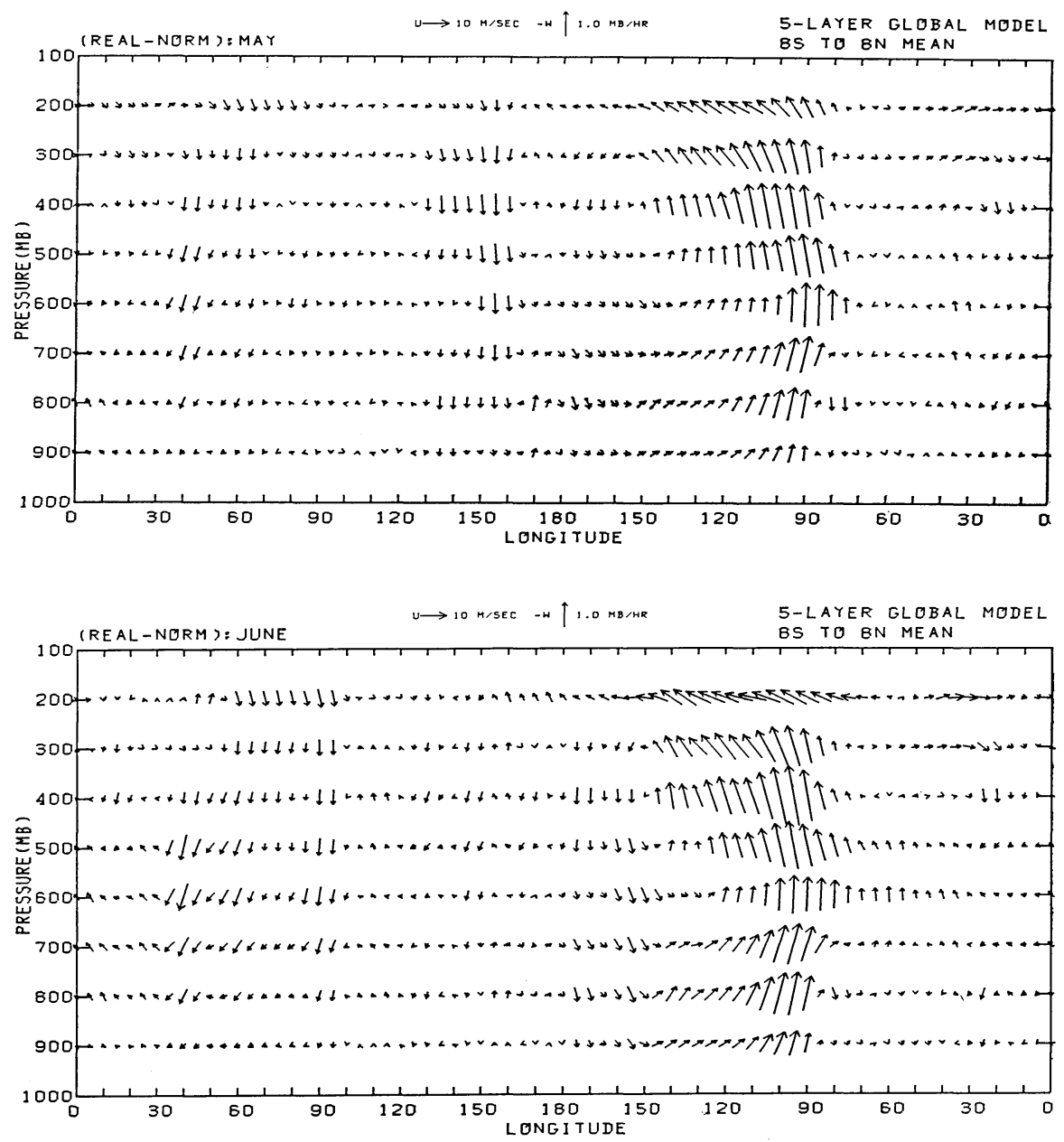

Fig. 8 Top: The monthly mean east-west circulation difference between " $R$ " and " $N$ " averaged over the equatorial belt $\left(8^{\circ} \mathrm{N}-8^{\circ} \mathrm{S}\right)$ for May. Bottom : Same as the top panel excep for June. 
In our case, descending anomalies are strong around $150^{\circ} \mathrm{E}$ in May and around $150^{\circ} \mathrm{W}$ in June (see Fig. 8).

Other maked decrease of precipitation is found over the north Indian Ocean. This is caused by the downward branch of the anomalous east-west circulations in the equatorial zone.

East-west circulation anomalies averaged over the $8^{\circ} \mathrm{N}$ and $8^{\circ} \mathrm{S}$ are shown in Fig. 8 . Well organized ascending anomalies exist around $90^{\circ} \mathrm{W}-120^{\circ} \mathrm{W}$. Large descending anomalies can be found around $30^{\circ} \mathrm{E}-60^{\circ} \mathrm{E}$ and $130^{\circ} \mathrm{E}-160^{\circ} \mathrm{E}$ for May, and $30^{\circ} \mathrm{E}-90^{\circ} \mathrm{E}$ and $150^{\circ} \mathrm{W}-170^{\circ} \mathrm{W}$ for June. Both the ascending and descending motions over the equatorial Pacific corresponed well with the positive and negative SSTAs in Fig. 2. It is noted that both precipitation and east-west circulations follow changes in the location and intensity of SSTA faithfully.

Walker circulation under normal condition consists of ascending motion over the western Pacific and descending motion over the eastern Pacific. Overall circulation anomaly indicates the weakening of the Walker circulation. In fact, " $R$ " show that the usual descending motion over the east Pacific is completely replaced by a strong ascending motion. The intensity of the ascending motion is even larger than that over the maritime continent.
Therefore the normal Walker circulation is completely destroyed in " $R$ " by the SSTA.

In the upper troposphere a large easterly anomaly over the eastern Pacific is an outstanding feature for both May and June. Westerly can be seen to the east of the main ascending branch, although the magnitude is less than that of the easterly. In the lower layer, westerly is most noticeable over the eastern Pacific. Fig. 9 shows the difference of surface stress between " $R$ " and " $N$ ". In the equatorial Pacific, westerly stress is large and its magnitude is about $0.03 \mathrm{~N} / \mathrm{m}^{2}$. This westerly stress, when operated on the sea surface, will suppress the upwelling, and thus has a positive feedback to the warm SSTA in the eastern equatorial Pacific, if we separate advective effects from the discussion. This stress will also contribute to move the positive SSTA toward east. The easterly stress is discernible over the subtropical central and western Pacific.

Fig. 10, 11 and 12 show the latitude-height cross section of circulation anomaly for the eastern Pacific, the western Pacific and the Indian Ocean, respectively. Month-to-month variation is large for the western Pacific (Fig. 11), while other two regions show small variations. This difference is mainly explained by month-to-month variation of the SSTA over the western Pacific as already mentioned. It
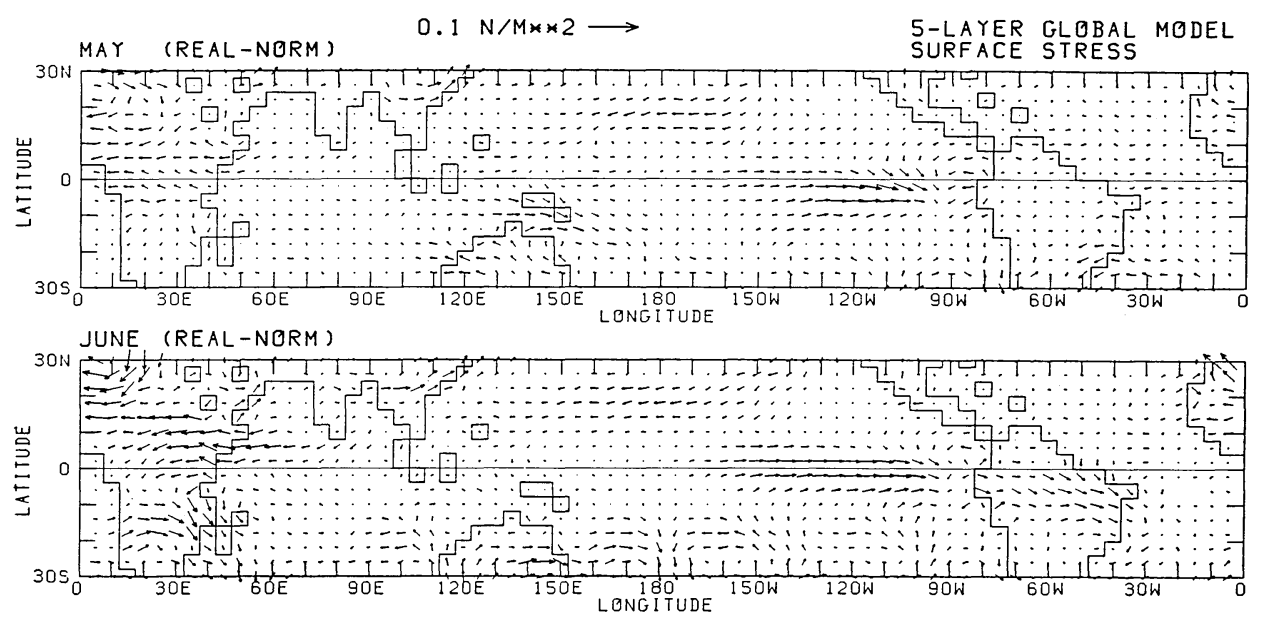

Fig. 9 Top: The monthly mean difference of surface stress between " $R$ " and " $N$ " for May. A reference arrow is shown at the top of the figure. Bottom: Same as the top panel except for June. 

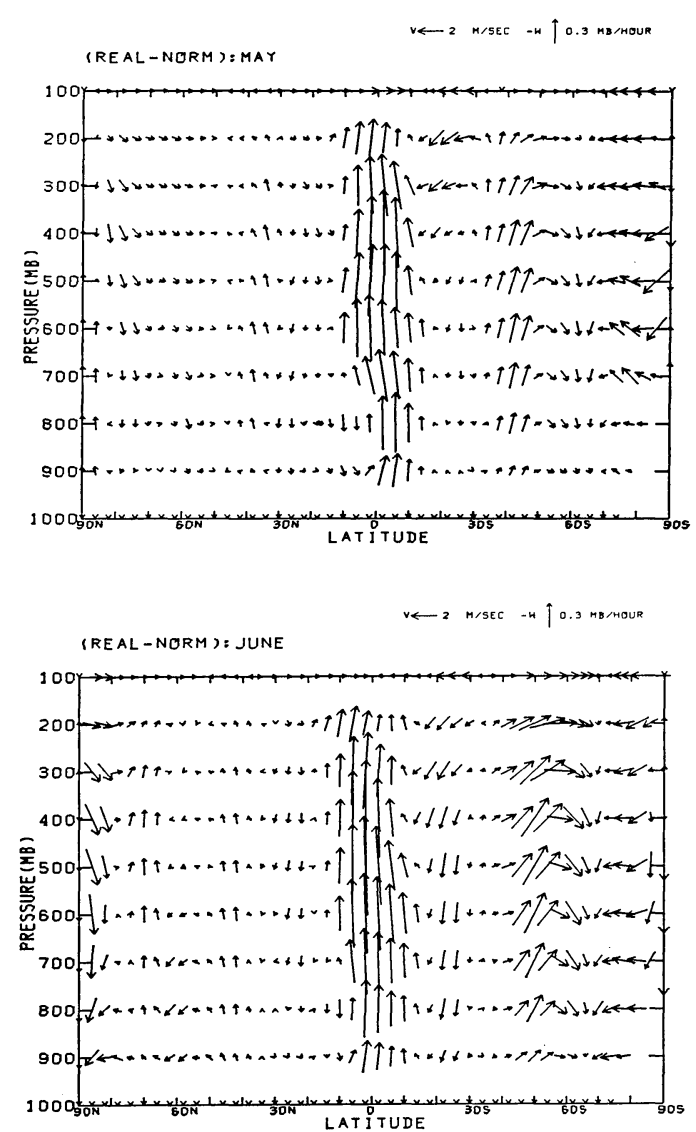

Fig. 10 Top: The monthly mean meridional circulation difference between " $R$ " and " $N$ " over the eastern Pacific zone $\left(120^{\circ} \mathrm{W}-60^{\circ} \mathrm{W}\right)$ for May. A reference arrow is shown at the top of the panel. Bottom: Same as the top panel except for June.

is interesting that the anomalous meridional flows are not closed in the local meridional plane. The large upward motion over the equatorial eastern Pacific does not have a compensating downward motion within the same longitudinal region. Compensating downward motion is mainly seen in the equatorial vertical plane at other longitudes. This suggest that the concept of intensifying local Hadley circulation is not suited to the circulations induced by equatorial SSTAs. In fact, east-west response is much larger than northsouth response. When there is a heating just over the equator, adiabatic cooling by ascending motions is favored to restore a thermal balance. Horizontal convergence is required
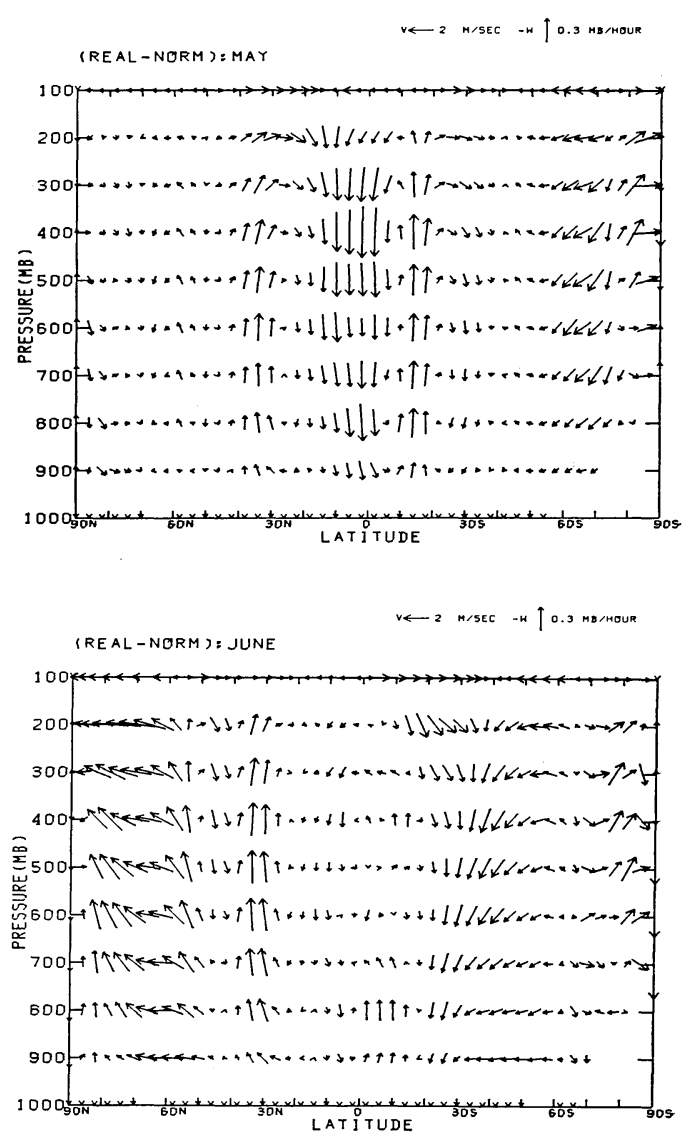

Fig. 11 Same as Fig. 10 except for the western Pacific zone $\left(120^{\circ} \mathrm{E}-160^{\circ} \mathrm{E}\right)$.

to maintain ascending motions. There are two ways of convergent motion, one the convergent motion in the north-south direction and the other in the east-west direction. The former suffers the Coriolis acceleration although the Coriolis factor is small in low latitudes. While the latter is free from the Coriolis acceleration. This asymmetry in the two types of convergent motion will basically explain the present results.

Over the equatorial Indian ocean is found a descending motion, especially in June (see Fig. 12). As noted previously, precipitation is suppressed in this area. There is also less precipitation in the southern part of India (see Fig. 6). The descending motion in these area is considered a part of the east-west circulation (see Fig. 8), although the circulation is not closed well in the equatorial vertical plane at this longitude. Overall 

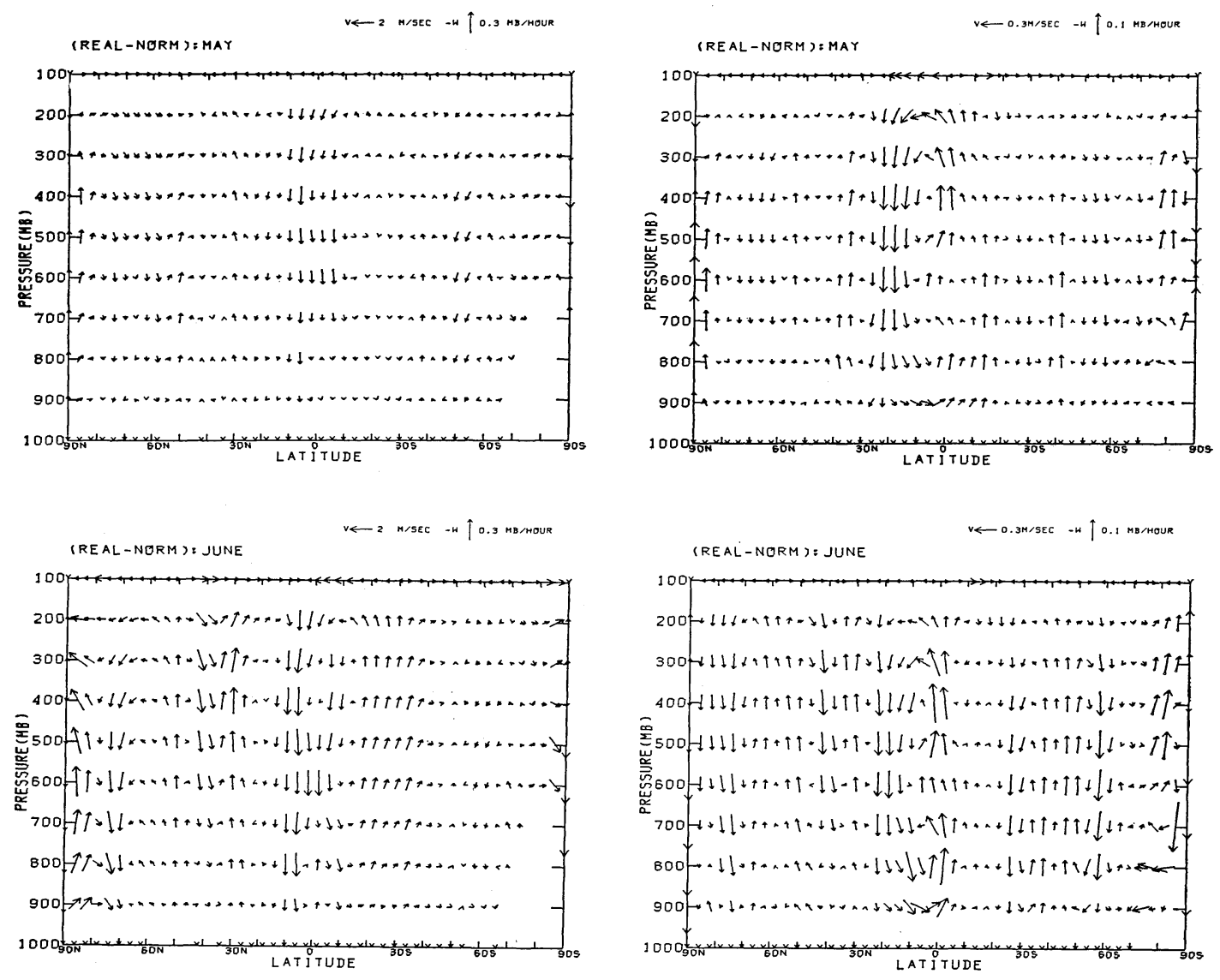

Fig. 12 Same as Fig. 10 except for the Indian Ocean $\left(30^{\circ} \mathrm{E}-120^{\circ} \mathrm{E}\right)$.

symptoms indicate an inactive Indian summer monsoon. What is indicated in the present study would be subsiding motions are favored over the equatorial Indian Ocean including the southern part of India when the SSTA is absent in that area. This sense is consistent with the observed relationship of less Indian monsoon rainfall with the positive SSTA over the eastern equatorial Pacific (Angell, 1981; Rasmusson and Wallace, 1983; Shukla and Paolino, 1983).

When the anomalous meridional flows are averaged zonally, the intensity of the flow becomes almost one order less as shown in Fig. 13. We notice a slight intensification of the Hadley cell. This is commonly seen in the El Niño experiment under perpetual January condition (Tokioka et al., 1985). Intensified sinking motion is seen around $20^{\circ} \mathrm{N}$.

Fig. 13 Same as Fig. 10 except for zonal mean.

\section{Global response}

In this section characteristics of the global response is studied. Statistical significance of the differences is assessed with the use of the Student's $t$-test. Emphasis is placed upon the extratropical response to the SSTA. Fig. 14 shows the sea level pressure differences between " $R$ " and " $N$ " for June. In the tropics, the pattern in May is similar to the one in June. In the extratropics, the magnitude in May is less than that in June (The figure for May is not shown). The Student's $t$-statistic test is applied to individual grid points (Fig. 15). Our null hypothesis is that the means of two groups, " $R$ " and " $N$ " are equal. We have estimates of ensemble average, $x_{R}$ and $x_{N}$, and estimates of standard deviation, $S_{R}$ and $S_{N}$. Under the assumption that two populations have the same standard 
Table 1 Significance levels from the two-tailed $t$-test with 8 degrees of freedom.

\begin{tabular}{|c|c|}
\hline$t$ & Signiflcance level $(\%)$ \\
\hline 1.397 & 20.0 \\
\hline 1.860 & 10.0 \\
\hline 2.306 & 5.0 \\
\hline 2. 896 & 2.0 \\
\hline 3. 355 & 1.0 \\
\hline 5.041 & 0.1 \\
\hline
\end{tabular}

deviation, the $t$-value is given as

$$
\begin{aligned}
t= & \frac{\left(x_{R}-x_{N}\right)}{\left\{\left(n_{R}-1\right) S_{R}^{2}+\left(n_{N}-1\right)\right.} \overline{\left.S_{N}^{2}\right\}^{1 / 2}} \\
& \times\left\{\begin{array}{c}
n_{R} n_{N}\left(\frac{\left.n_{R}+n_{N}-2\right)}{n_{R}+n_{N}}\right. \\
n^{1 / 2}
\end{array}\right.
\end{aligned}
$$

where $n_{R}$ and $n_{N}$ are the number of samples in " $R$ " and " $N$ " respectively and are equal to $n(=5)$ in our case. Thus

$$
t=\left(x_{R}-x_{N}\right)\left(\begin{array}{c}
n \\
S_{R}^{2}+S_{N}^{2-}
\end{array}\right)^{1 / 2}
$$

The number of degrees of freedom for the test is $n_{R}+n_{N}-2$ and is 8 in our case. Table 1 shows the $t$-values associated with various significance levels, using the two-tailed $t$-test.

In low latitudes, anomaly has a global scale. The center of negative anomaly is over the eastern Pacific, while those of positive anom- aly are over the western Pacific and Indian Ocean for both months. The pattern in the tropics is similar to that of Keshavamurty's (1982) eastern Pacific anomaly case. Shaded area in Fig. 15 shows the significant area at $5 \%$ level. Most of large anomalies are significant at 5\% level for both May and June. It is not surprising that the high significant level is assessed over the large SSTA area. However, the high significant level of positive anomaly over the western Pacific is interesting.

The Southern Oscillation Index (SOI) is defined as a normalized surface pressure difference between Tahiti $\left(18^{\circ} \mathrm{S}, 150^{\circ} \mathrm{W}\right)$ and Darwin $\left(12^{\circ} \mathrm{S}, 131^{\circ} \mathrm{E}\right)$ whose locations are shown in Fig. 14. Extremely low SOIs are mostly associated with El Niño events. Simulated Tahiti-Darwin surface pressure anomalies are $-0.07 \mathrm{mb}$ in May and $0.85 \mathrm{mb}$ in June. If observed standard devirtions for the corresponding months are adopted from Trenberth (1984), simulated normalized SOI is -0.09 in May and 1.15 in June. Despite the intense El Niño event, these values are far from the typical low values in El Niño. However, the present result is consistent with the observed values of the Index. These near-normal values are accounted for the eastward shift of east-west surface pressure

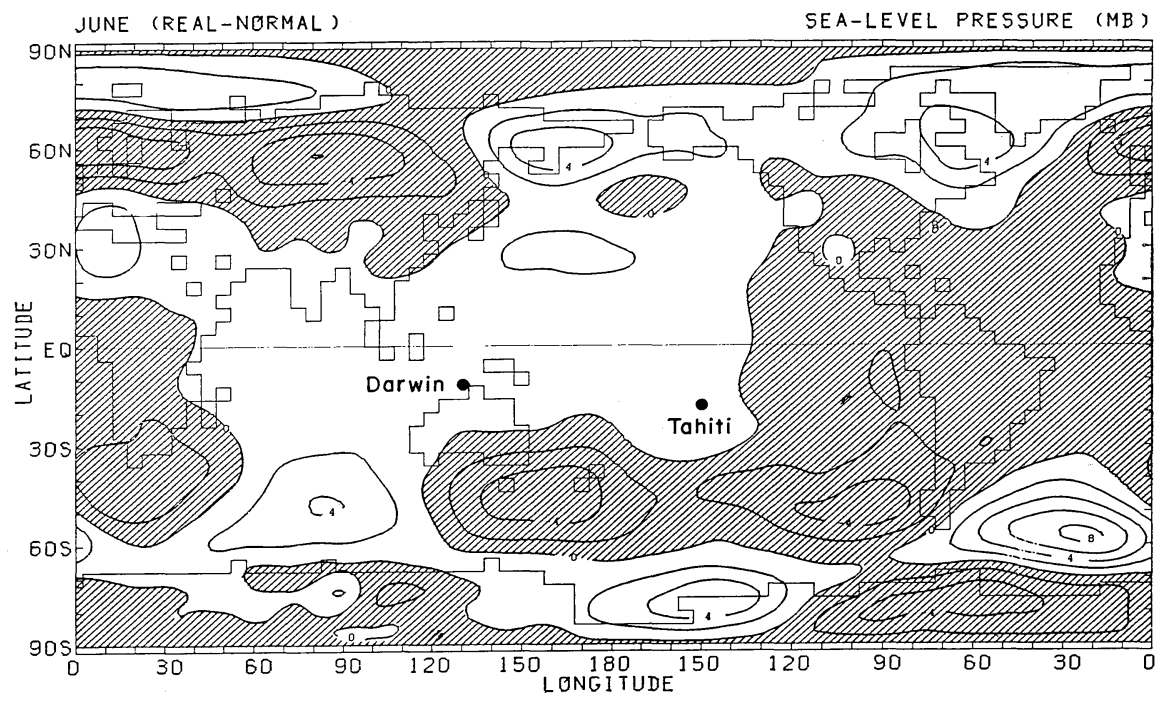

Fig. 14 Sea-level pressure difference between " $R$ " and " $N$ " for June. Negative regions are shaded. Contour interval is $2 \mathrm{mb}$. 


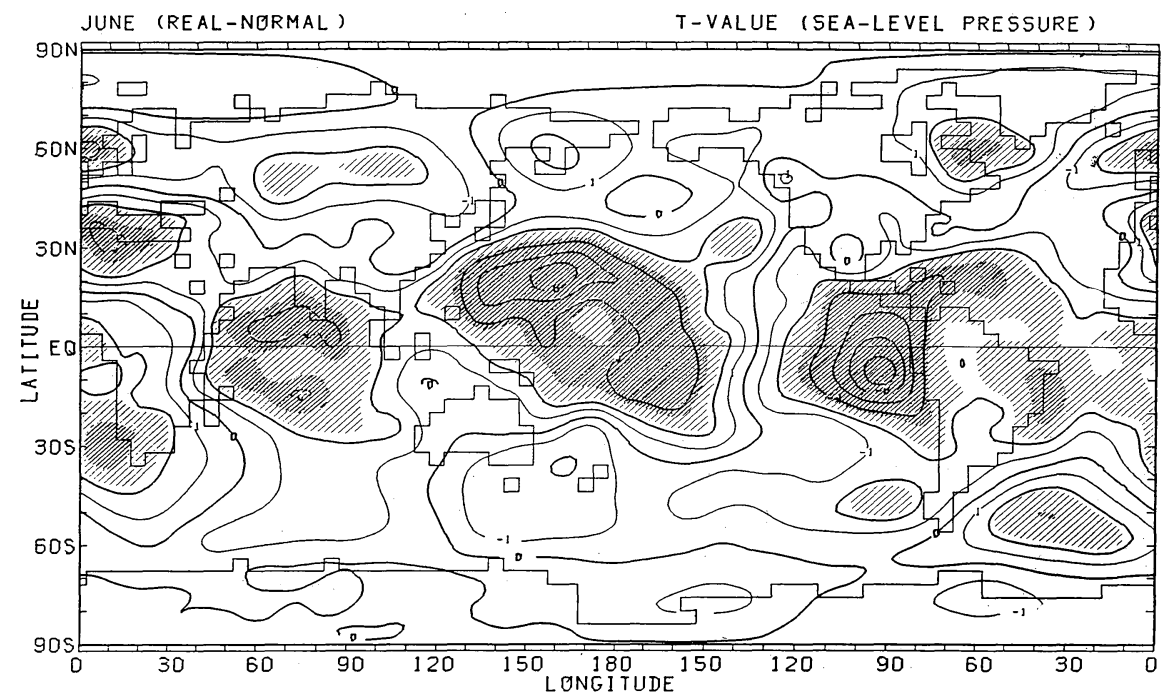

Fig. 15 The $t$-value for sea-level pressure difference (Fig. 14) for June. Lightly shaded regions are statistically significant at $5 \%$ level. Darkly shaded regions are statistically significant at $1 \%$ level. Thick contour interval is 2 . Thin contours are 1 and -1 .

seesaw pattern shown in Fig. 14. Although the SOI is not so low in this case, the normal Walker circulation is diminished as seen in Section 4. If a point off the Peru coast is chosen instead of Tahiti, the computed SOI will be low. The present case tells us that the SOI is not always a good indicator of the Southern Oscillation and El Niño. This is an example where the SOI loses its meaning.

In the extratropics, the relatively broad significant regions can be found only around the South America in May. However, highs over the Labrador Sea and the Mediterranean and low over northern Europe are highly significant in June.

Fig. 16 shows the $500 \mathrm{mb}$ height anomaly field for June; Fig. 17 shows $t$-statistics for the same field. Positive anomalies prevail in the tropics, indicating that the tropical troposphere is heated rather uniformly by the SSTA, as found in perpetual January case (Tokioka et al., 1985).

Anomalies in the extratropics are contrasted with those in the tropics both in the horizontal scale and the vertical structure. In the extratropics the anomaly field has smaller horizontal scale and barotropic nature. In the western hemisphere, we notice wave trains in both hemispheres and the anomaly pattern has characteristics of the Rossby wave response emanating from the eastern equatorial Pacific. In June, we find a negative region over the western United States, a positive region over eastern Canada and a negative region over the North Atlantic. This pattern is similar to the Pacific/North American (PNA) pattern studied by Horel and Wallace (1981) for the northern winter, although the location is shifted eastward in the present case. This suggests that the response in the extratropics is sensitive to the location of SSTA in the tropics. A similar pattern can be seen in the same longitudinal area in May, although it is not so clear and is shifted southward compared with that in June (The figure for May is not shown). This phase shift seems to be attributed mainly to the zonal flow difference between the two months. In June the westerly in mid-latitudes weakened and the subtropical jet axes moved poleward. Over the northern Canada the zonal flow was nearly zero or weak easterly in May, while the flow was weak westerly in June. This explains the northward shift of the PNA-like pattern in June in consistent with the propagation theory of Rossby waves (Hoskins and Karoly, 


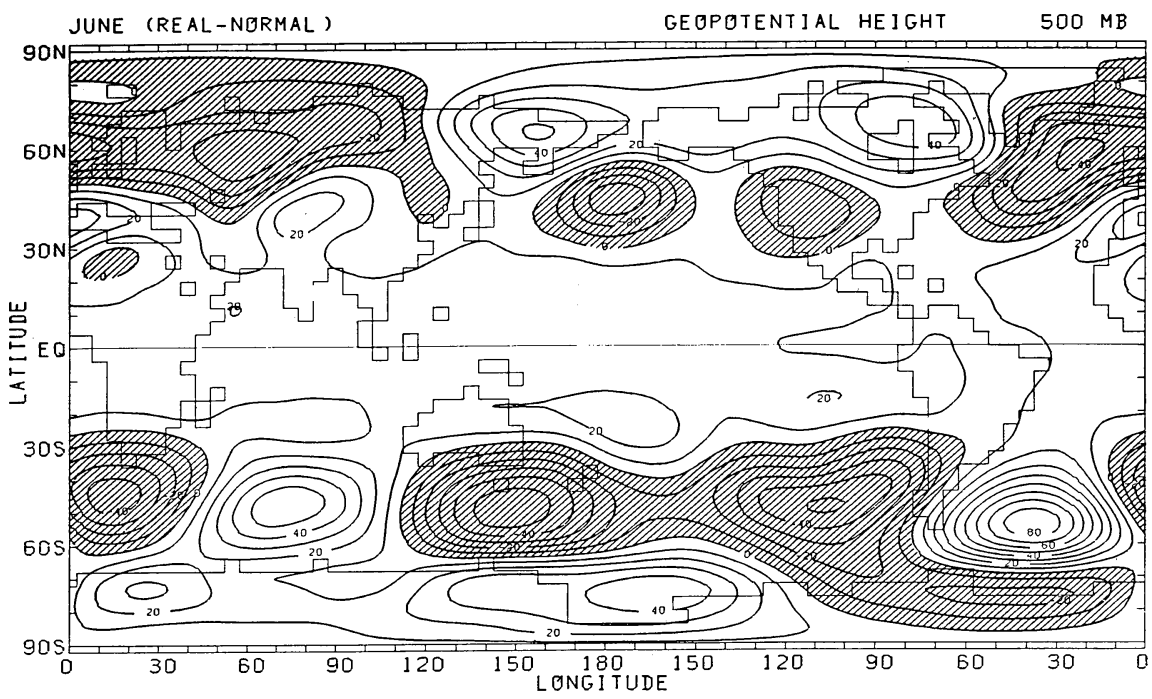

Fig. 16 Same as Fig. 14 except for $500 \mathrm{mb}$ geopotential height. Contour interval is $10 \mathrm{gpm}$.

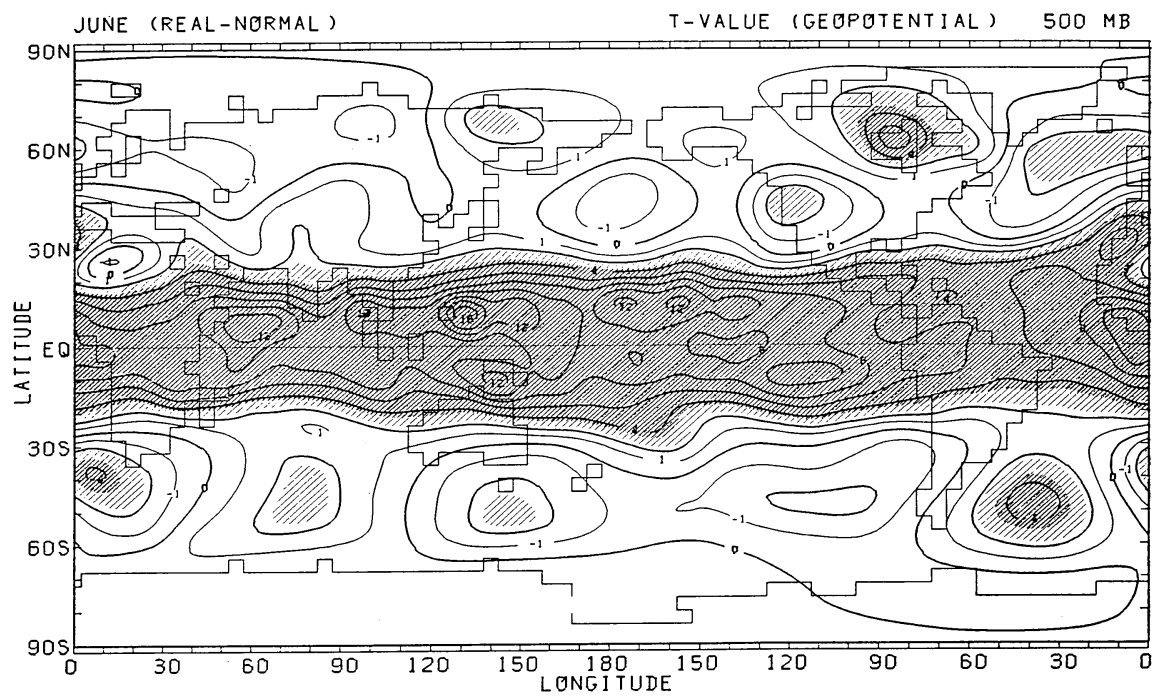

Fig. 17 Same as Fig. 15 except for $500 \mathrm{mb}$ geopotential height.

1981).

We find a negative anomaly over the North Pacific separated from the one over the western part of the United States. This anomaly can not be explained simply by the linear propagation theory. Some speculations on its cause are made in Section 6. In the southern mid-latitudes, alternating highs and lows surrounding the latitude circle are noticeable. Their centers are mostly significant at $5 \%$ level in June.
In general the extratropical response in May is weaker than that in June. It is reasonable because it takes more than 10 days for the influence of SSTA to propagate all over the globe and make the two groups of runs nearly independent satistically (see, e.g., Fig. 3). Wind differences at $200 \mathrm{mb}$ and $800 \mathrm{mb}$ in June are shown in Fig. 18. Weakening of the Walker circulation can be confirmed again. Intensification and equatorward shift of subtropical jets over the area from the North 

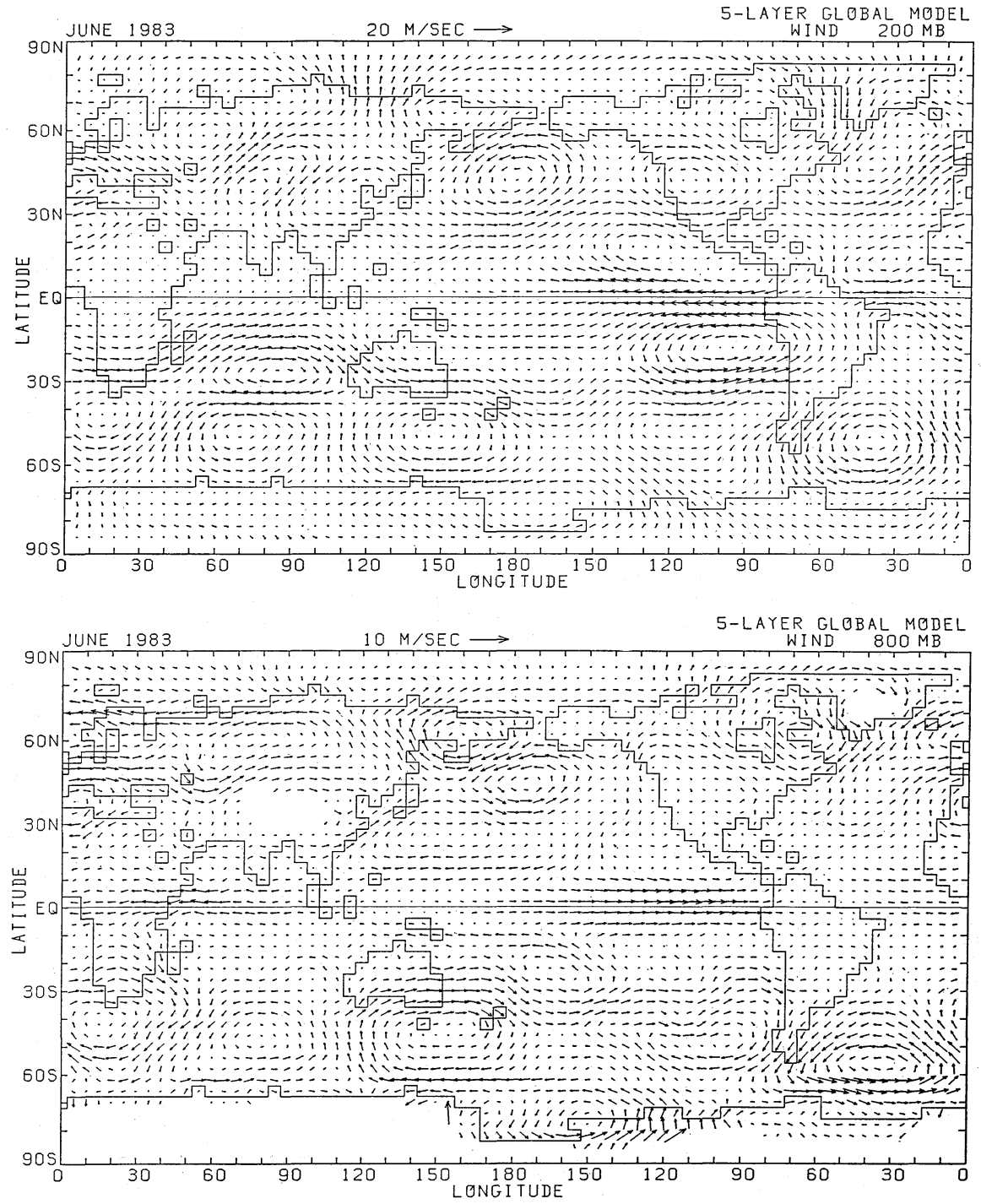

Fig. 18 Top: Wind difference at $200 \mathrm{mb}$ between " $R$ " and " $N$ " for June. Bottom : Same as the top panel except for $800 \mathrm{mb}$.

Pacific to the Atlantic and over the South Pacific is a prominent feature. This feature is actually observed in 1983 (Chen, 1983; Ropelewski, 1984).

Fig. 19 shows the $t$-values for the zonal wind difference at $200 \mathrm{mb}$ and $800 \mathrm{mb}$. Upper easterly and lower westerly over the central and eastern equatorial Pacific are highly significant. In addition, a highly significant region of lower easterly can be seen at $30^{\circ} \mathrm{W}-90^{\circ} \mathrm{E}$. These high $t$-values over the tropics are caused not only by large wind anomalies but by small standard deviations for " $R$ " and " $N$ ". Over the tropics, standard deviations in the model are much smaller than the observation when the SST is prescribed. Intensification of subtropical jets in both hemispheres is significant.

Fig. 20 shows differences of velocity potential fields between " $R$ " and " $N$ " and associated divergent wind fields at $300 \mathrm{mb}$ and $700 \mathrm{mb}$ for June. Maxima and minima of the velocity potential fields are situated over the equator as in January experiment (Tokioka 

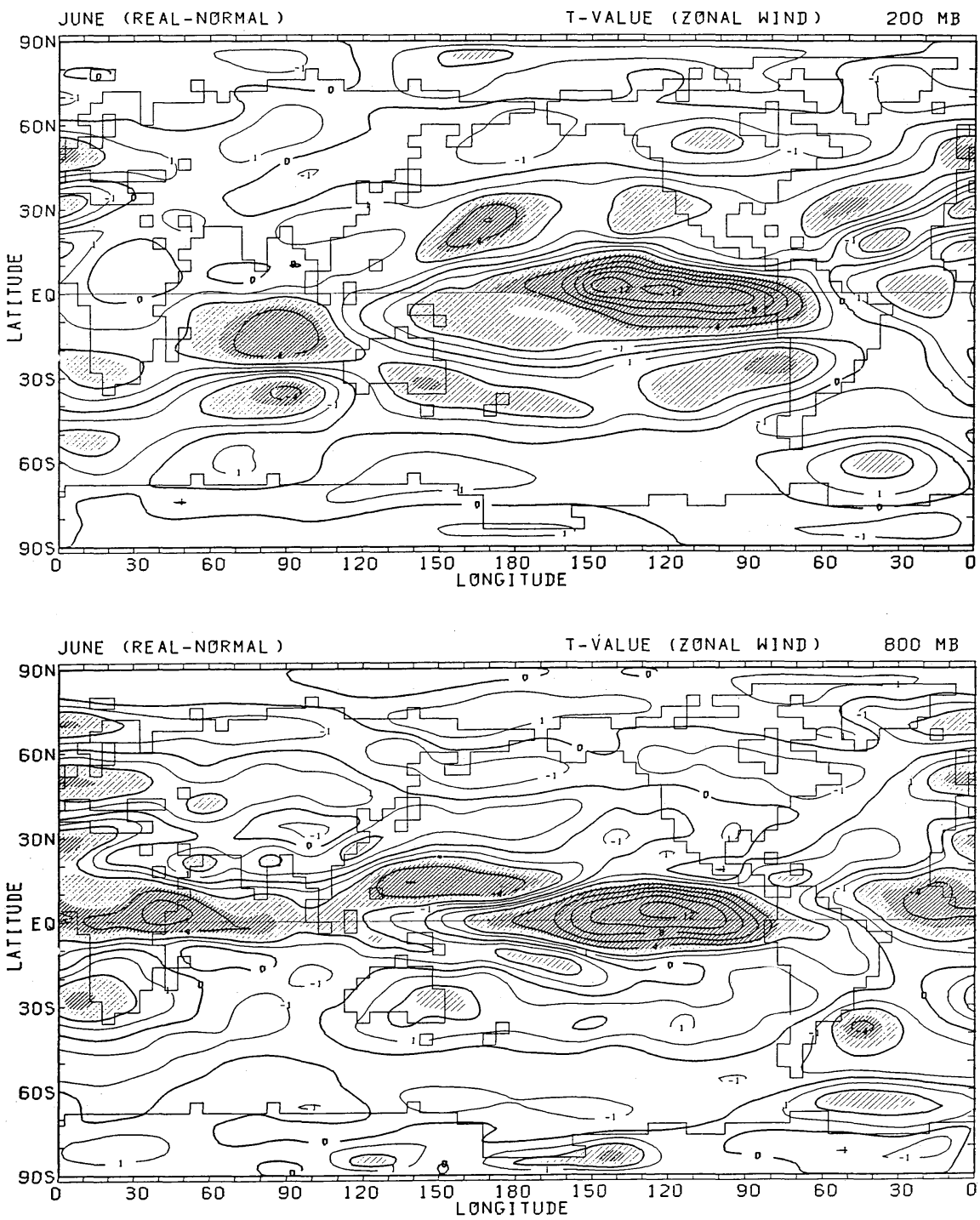

Fig. 19 Top: The $t$-values for zonal wind difference at $200 \mathrm{mb}$ for June. Light shading indicates region significant at 5\% level. Dark shading indicates region significant at $1 \%$ level. Thick contour interval is 2 . Thin contours are 1 and -1 .

et al., 1985) and the planetary scale wave structure, particularly wavenumber 1 and 2 , is dominant. The center of divergence at $300 \mathrm{mb}$ is located approximately at the center of heating, though the corresponding center of convergence at $700 \mathrm{mb}$ is shifted eastward by about $20^{\circ}$. Poleward flow at the upper level and counter equatorial flow at the lower level are clearly seen near the heating longitude. The poleward divergent flow contributes to the net intensification of the subtropical jets at the upper level. Note that the rotational wind component has equatorward direction at the longitudies near the heating center and the total meridional wind is equatorward at the upper level as shown in Fig. 10. Theoretical studies (e.g., Gill, 1980; Lim and Change, 1983) show that upper equatorward flows (lower poleward flows) of anticyclonic pair (cyclonic pair) are situated near the heating longitude and our results accord with their results. As for the east-west flow over 

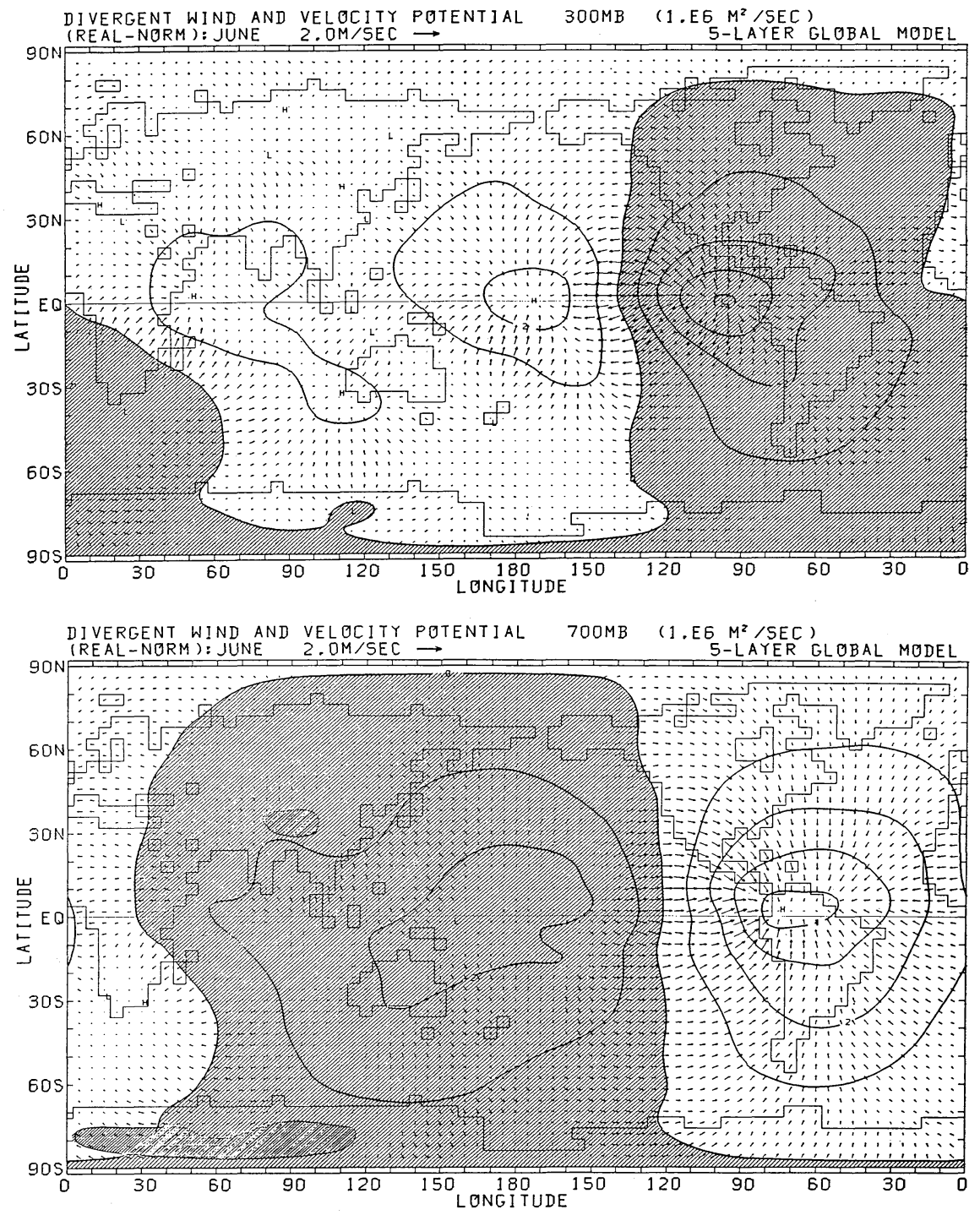

Fig. 20 The divergent wind and velocity potential differences at $300 \mathrm{mb}$ between " $R$ " and " $N$ " for June. Contour interval is $10^{6} \mathrm{~m}^{2} / \mathrm{s}$. Negative regions are shaded. A reference arrow is shown at the top of the panel. Bottom: Same as the top panel except for $700 \mathrm{mb}$.

the equator, the directions of divergent winds are the same as those of rotational winds, though the amplitudes of divergent winds are much smaller than those of rotational winds (Compare Fig. 18 with Fig. 20). The eastwest circulation in the tropics is stronger on the west side of the heating center than that on the east side.

Fig. 21 shows the latitude-height section of temperature difierence in June. Large positive anomalies are found in the upper equatorial troposhere. Near the surface positive anomalies lie in low-latitudes, and negative in middle-latitudes. The global mean surface temperature in June is increased as much as $0.24^{\circ} \mathrm{K}$ by the SSTA in our case. Angell and Korshover (1984) showed the global mean temperature in the early summer of 1983 was above nomal $\left(0.5^{\circ} \mathrm{K}\right)$.

Fig. 22 shows the latitude-height section 


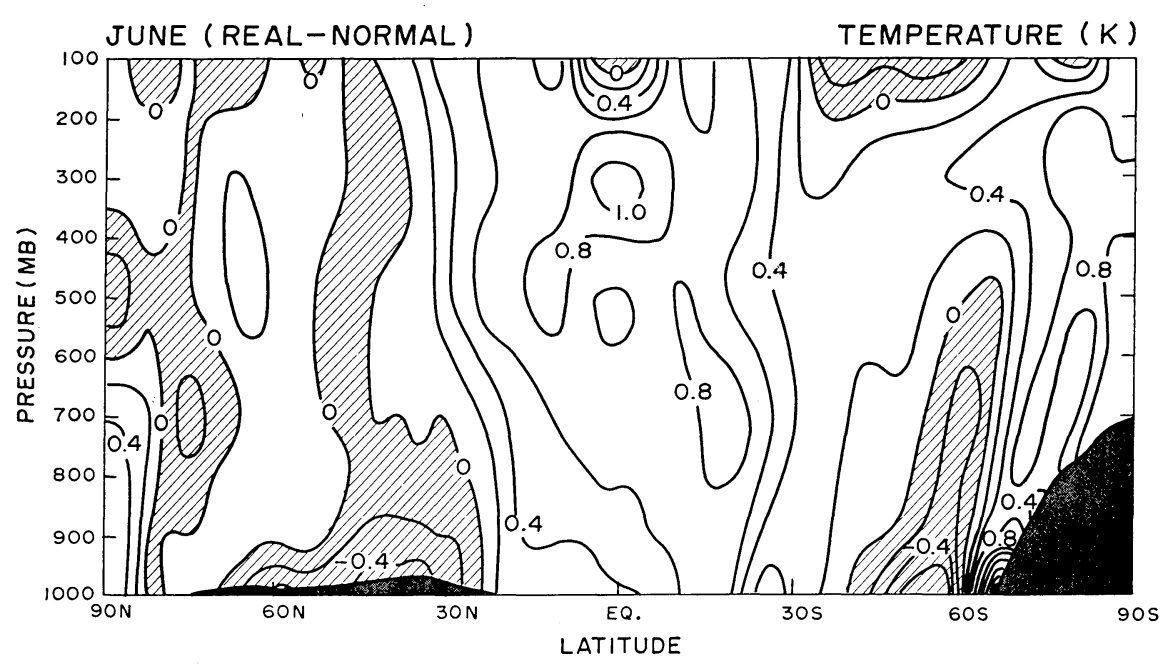

Fig. 21 The latitude-height section of temperature difference between " $R$ " and " $N$ " for June. Negative regions are shaded. Contour interval is $0.2^{\circ} \mathrm{K}$.

of simulated zonal mean wind for " $N$ " and the difference between " $R$ " and " $N$ ". Subtropical jets are located at about $40^{\circ} \mathrm{N}$ and $30^{\circ} \mathrm{S}$ in the upper troposphere. Positive anomalies are found in the equatorward sides of the jets in the uppermost layer at about $30^{\circ} \mathrm{N}$ and $25^{\circ} \mathrm{S}$. Hence the subtropical jets are intensified and shifted equatorward. Equatorial easterly is increased in the upper layer.

One interesting difference between " $R$ " and " $N$ " is found by applying the space-time spectral analysis to the daily geopotential field data. Fig. 23 shows the spectral analysis for the wavemumber 1 geopotential field at $30^{\circ} \mathrm{N}$, $300 \mathrm{mb}$ during June. In " $R$ ", the westward moving five day wave has a significant peak. In " $N$ ", the peak exists at the westward moving five day period, but the power is much smaller than that in " $R$ ". This wave has a nearly symmetric structure with respect to the equator and has a maximum power at about $40^{\circ}$. Therefore, this wave is identified as the "5-day wave" (e.g., Madden and Julian, 1972; Madden, 1978) which is the $H_{2}^{1}$ mode of Hough function, theoretically predicted by the Laplace's tidal equations. However, we have found so far no observational evidence that the amplitude of 5-day wave was enhanced in June 1983.

\section{Summary and discussion}

We studied atmospheric response to the sea surface temperature anomalies observed in early summer of 1983 with the MRI.GCM. Two groups of run were performed, one with the observed SST in 1983 (" $R$ "), and the other with the climatological SST ("N"). Atmospheric response to the SSTA was studied by comparing the results of " $R$ " and " $N$ ". We found that many features of the differences are explained by the linear theory. Followings may be concluded from the present study.

1) In short-time response, equatorially trapped westward traveling Rossby and eastward traveling Kelvin wave responses are dominant in the tropics.

2) In short-time response, the quasibarotropic Rossby wave train emanating from the eastern equatorial Pacific is clearly detected in the middle-latitudes. In addition, the results suggest a possibility of a reflection of a Rossby wave near the subtropical critical latitudes. Present case study clearly demonstrates a process of eastablishing extratropical anomalies caused by equatorial SSTAs.

3) The equatorial steady wave response is seen in the monthly mean anomaly fields. Basic features of responses are similar to 

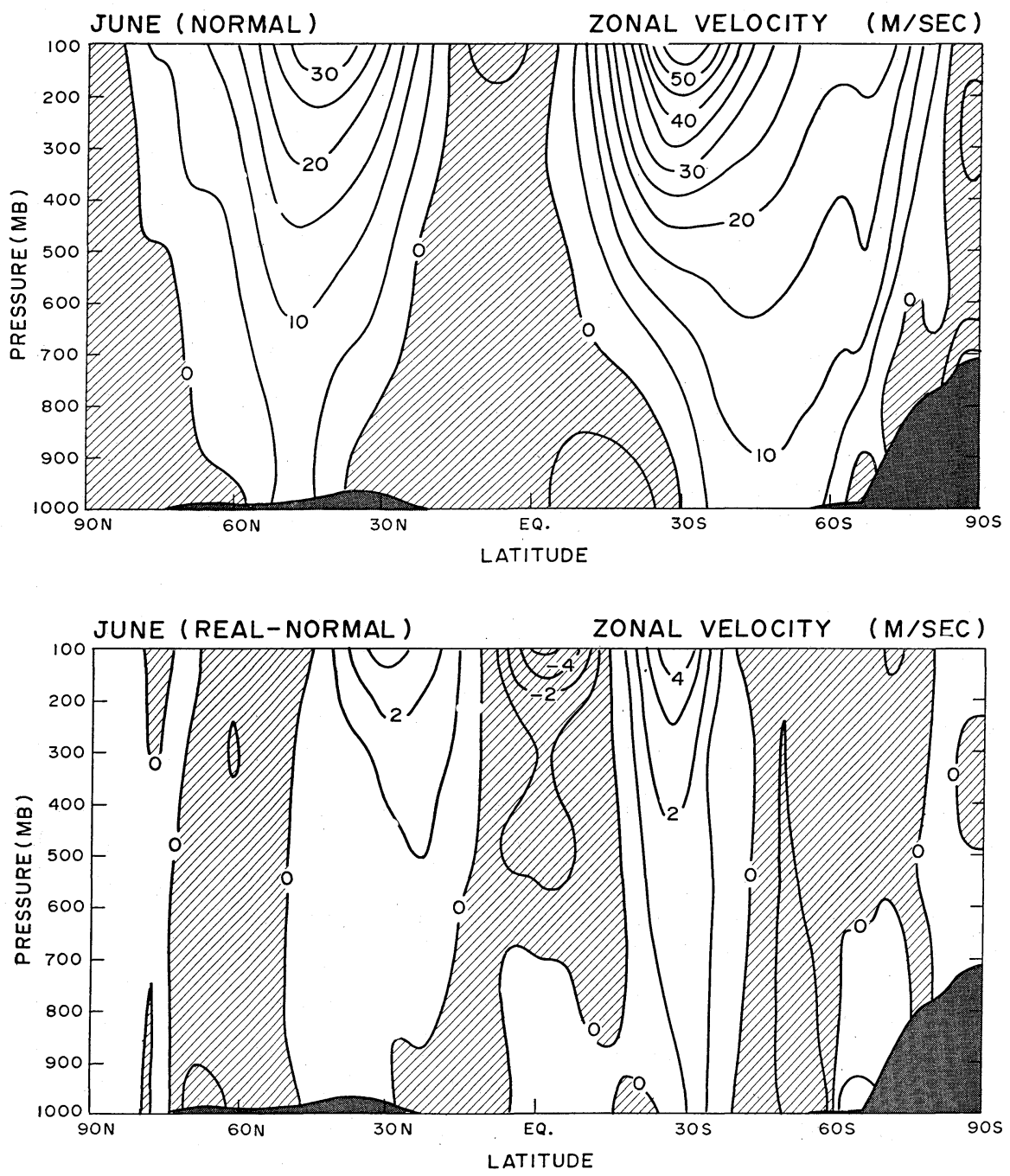

Fig. 22 Top: The latitude-height section of June zonal mean wind for " $N$ ". Easterly regions are lightly shaded. Contour interval is $5 \mathrm{~m} / \mathrm{s}$. Bottom: The latituceheight section of June zonal mean wind difference between " $R$ " and " $N$ ". Negative regions are shaded. Contour interval is $1 \mathrm{~m} / \mathrm{s}$.

those found in January case (Rowntree, 1972; Julian and Chervin, 1978; Shukla and Wallace, 1983; Blackmon et al.; 1983; Tokioka et al., 1985). The Walker circulation is diminished in " $R$ ". The remote response over the Indian Ocean is significant. In the upper troposphere, anomalous anti-cyclonic pair straddles the equator at the longitude of major warm SSTA and subtropical jets are intensified. Responses in the tropics and subtropics are mostly significant statistically and are sensitive to the intensity and location of the SSTA.
4) In the middle-latitudes, the response is sensitive to the location of SSTA in the tropics and to the zonal flow in both the tropics and the extratropics. Larger responses were obtained in the winter hemisphere (southern hemisphere). Previous GCM experiments on atmospheric response to the typical mature phase SSTA of El Niño are successful in reproducing the PNA pattern (e.g., Shukla and Wallace, 1983; Blackmon et al., 1983). In our case, a PNA-like pattern appeard in the northern hemisphere, shifted eastward from the 


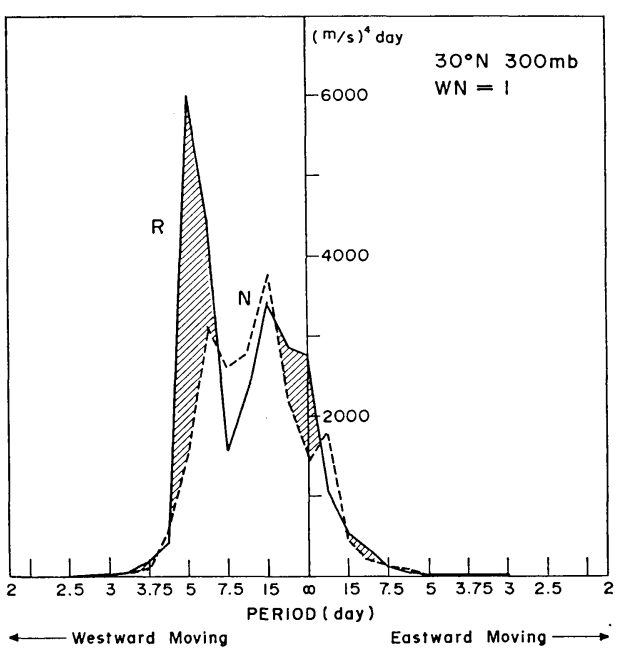

Fig. 23 Power spectrum for zonal wavenumber 1 component of geopotential field at $30^{\circ} \mathrm{N}, 300$ $\mathrm{mb}$ in June. The solid line denotes the mean spectrum for " $R$ ". The broken line denotes that for " $N$ ".

location in winter. This shift seems to coincide with the eastward shift of intense warm SSTA.

Besides the features summarized above, another anomaly is found in the North Pacific in our experiment especially in June (see Fig. 16 and 18). This low seems to be different from the North Pacific low found in the winter PNA as for their origins. The North Pacific low anomaly simulated in our experiment is not significant at $500 \mathrm{mb}$ at $5 \%$ level, while highly significant at $200 \mathrm{mb}(\sim 1 \%)$. This low is not explained as a direct Rossby wave response to the eastern equatorial Pacific SSTA. This low might be explained by a Rossby wave train of different origin, such as negative equatorial heating over the Indian ocean. Another possible cause might be found in nonlinear interactions of the zonal wind anomaly with the large-scale topograpy, espcially the Tibetan Plateau. The intensified subtropical jet may interact with the Tibetan Plateau and cause Rossby wave trains in the downsteam of the mountain. Further studies are needed to clarify the cause of the low.

The MRI.GCM-I has shortcomings in several respects (see Tokioka et al., 1984 ; Tokioka et al., 1985 ; and Kitoh and Tokioka, 1985). Simulated polar temperature near the tropopose level is systematically low compared to the observation. Hence a drift from the initial condition to the model's climate occurs in the present experiment during the first one month.

Top of the model $(100 \mathrm{mb})$ may be considered to be too low. The low top affects the results of simulation mainly in two ways. Firstly, the suppress of upward extension of the Hadley cell may affect the tropical circulation. Fortunately the performance of the model in the tropics is not so bad. Secondly the upper lid prevents the upword propagation of the planetary waves (wavenumber 1 and 2 ) especially in the winter hemisphere and deforms their structures. These deficiencies together with other shortcomings not mentioned above may become a severe limitation when comparisons of the present results with the observation are made. The subject will be investigated in the forthcoming paper.

On the revising stage of this paper, we noticed Fennessy et al. (1985) perfomed sensitivity experiments to observed equatorial Pacific SSTA in the $1982 / 83$ winter. They obtained a significant increase of precipitation over the eastern equatorial Pacific, in agreement with observed outgoing longwave radiation (OLR) anomalies. Our results for early summer case also showed a significant increase of precipitation ovea the same region, in agreement with the observed OLR anomalies. Moreover the horizontal flow anomalies over the tropics and a part of mid-latitudes in our experiment show a good agreement with the observation. Detailed comparisons with the observation will also be given in the forthcoming paper.

\section{Acknowledgement}

The authors wish to thank Prof. Y. Mintz, Maryland Univ., and Prof. A. Arakawa, the UCLA, for kindly permitting us to use the albedo and the groundwetness data; and $\mathrm{Mr}$. J.A. Spahr for processing and sending the data tape. Thanks are extended to Mr. Y. Tanaka and Mr. T. Ueno, Japan Meteorological Agency for providing the SST data and the initial conditions, and to Miss H. Imai for drafting. The initial conditions are analyzed at the Electronic Computation Center, Japan 
Metorological Agency. The reviewers' comments were helpfull for improving the original manuscript.

The numerical time integration of the model was made with the HITAC M-200H computer at the MRI.

\section{References}

Alexander, R.C. and R. L. Mobley, 1976: Monthly average sea-surface temperatures and ice-pack limits on a $1^{\circ}$ global grid. Mon. Wea. Rev., 104, 143-148.

Angell, J.K., 1981: Comparison of variation in atmospheric quantities with sea surface temperature variations in the equatorial eastern Pacific. Mon. Wea. Rev., 109, 23C-243.

and J. Korshover, 1984: Comparison of tropospheric temperatures following Agung and El Chichon volcanic eruptions. Mon. Wea, Rev., 112, 1457-1463.

Arakawa, A. and Y. Mintz, 1974: The UCLA Atmospheric General Circulation Model, Notes distributed at the workshop. 25 March-4 April 1974, UCLA.

- and W.H. Schubert, 1974: Interaction of a cumulus cloud ensemble with the large-scale environment, Part I. J. Atmos. Sci., 31, 674-701.

- and V. Lamb, 1976: Computational design of basic dynamical processes of the UCLA general circulation model. Methods in Computational Physics, Vol. 17 (Academic Press Inc., New York 1977), pp. 173-265.

Bjerknes, J., 1966: A possible response of the atmospheric Hadley circulation to equatorial anomalies of ocean temperature. Tellus, 18, 820829.

- 1969: Atmospheric teleconnections from the equatorial Pacific. Mon. Wea. Rev., 97, 163172.

Blackmon, M. L., J. E. Geisler and E. J. Pitcher, 1983 : A general circulation study of January climate anomaly patterns associated with interannual variation of equatorial Pacific sea surface temperatures. J. Atmos. Sci., 40, 1410-1425.

Branstator, G., 1983: Horizontal energy propagation in a barotropic atmosphere with meridional and zonal structure. J. Atmos. Sci., 40, 16891708.

Chen, W. Y., 1983: The climate of spring 1983A season with persistent global anomalies associated with El Niño. Mon. Wea. Rev., 111, 2371-2384.

Deardorff, J. W., 1972: Parameterization of the planetary boundary layer for use in general circulation models. Mon. Wea. Rev., 100, 93-106.

Fennessy, M. J., L. Marx and J. Shukla, 1985: General circulation model sensitivity to $1982-83$ equatorial Pacific sea surface temperature anom- alies. Mon. Wea. Rev. (in press).

Gill, A.E., 1980: Some simple solutions for heatinduced tropical circulation. Quart. J.R. Met. Soc., 106, 447-462.

Horel, J. D. and J. M. Wallace, 1981: Planetaryscale atmospheric phenomena associated with the Southern Oscillation. Mon. Wea. Rev., 109, 813829.

Hoskins, B. J. and D. Karoly. 1981: The steady linear response of a spherical atmosphere to thermal and orographic forcing. J. Atmos. Sci., 38, $1179-1196$.

Julian, P. R. and R. M. Chervin, 1978: A study of the Southern Oscillation and Walker circulation phenomenon. Mon. Wea. Rev., 106, 1433-1451.

Katayama, A., 1972: A simplified scheme for com. puting radiative transfer in the troposphere. Tech. Report No. 6, Department of Meteorology, UCLA, $77 \mathrm{pp}$.

Keshavamurty, R. N., 1982: Response of the atmosphere to sea surface temperature anomalies over the equatorial Pacific and the teleconnections of the Southern Oscillation. J. Atmos. Sci., 39, 1241-1259.

Kitoh, A. and T. Tokioka, 1985: A simulation of the tropospheric general circulation with the MRI atmospheric general circulation model. Part II : The July performance. (to be submitted for publication).

Krueger, A.F., 1983: The climate of autumn 1982 -With a discussion of the major tropical Pacific anomaly. Mon. Wea. Rev., 111, 1103-1118.

Lau K.-M. and H. Lim, 1982: Thermally driven motions in an equatorial $\beta$-plane: Hadley and Walker circulations during the winter monsoon. Mon. Wea. Rev., 110, 336-353.

- and - 1984: On the dynamics of equatorial forcing of climate teleconnections. J. Atmos. Sci., 41, 161-176.

Lim, H. and C.-P. Chang, 1983: Dynamics of teleconnections and Walker circulations forced by equatorial heating. J. Atmos. Sci., 40, 1897-1915.

Madden, R. A., 1978: Further evidence of traveling planetary waves. J. Atmos. Sci., 35, 1605-1618. P and P. Julian, 1972: Further evidence of global-scale 5-day pressure waves. J. Atmos. Sci., 29, 1464-1469.

Matsuno, T., 1966: Quasi-geostrophic motions in the equatorial area. J. Meteor. Soc. Japan, 44, $25-43$.

Nigam, S. and I. M. Held, 1983: The influence of a critical latitude on topographically forced stationary waves in a barotropic model. J. Atmos. Sci., 40, 2610-2622.

Philander, S. G. H., 1983 : El Niño Southern Oscillation phenomena. Nature, 302, 295-301.

Posey, J. W. and P.F. Clapp, 1964: Global distribution of normal surface albedo. Geofis. Int., 4, $33-48$. 
Quiroz, R.S., 1983: The climate of the "El Niño" winter of 1982-1983-A season of extraordinary climatic anomalies. Mon. Wea. Rev., 111, 16851706.

Randall, D. A., 1976: The interaction of the planetary boundary layer with large-scale circulations. Ph. D. Thesis, UCLA, 247 pp.

Rasmusson, E. M. and T.H. Carpenter, 1982: Variations in tropical sea surface temperature and surface wind fields associated with the Southern Oscillation/El Niño. Mon. Wea. Rev., 110. 354384 .

- and J.M. Wallace, 1983: Meteorological aspects of the El Niño-Southern Oscillation. Science, 222, 1195-1202.

Ropelewski, C.F., 1984: The climate of summer 1983-A season of contrasts and extremes. Mon. Wea. Rev., 112, 591-609.

Rowntree, P.R., 1972: The influence of tropical east Pacific Ocean temperatures on the atmosphere. Quart. J. Roy. Meteor. Soc., 98, 290321.

Shukla, J., 1975: Effect of Arabian sea-surface temperature on Indian summer monsoon: A numerical experiment with the GFDL model. $J$. Atmos. Sci., 32, 503-511.

and D. A. Paolino, 1983: The Southern Oscillation and long-range forecasting of the summer monsoon rainfall over India. Mon. Wea. Rev., 111, 1830-1837.

and J. M. Wallace, 1983 : Numerical simulation of the atmospheric response to equatorial
Pacific sea surface temperature anomalies. $J$. Atmos. Sci., 40, 1613-1630.

Suarez, M. J., A. Arakawa and D. A. Randall, 1983 : The parameterization of the planetary boundary layer in the UCLA general circulation model: Formulation and results. Mon. Wea. Rev., 111, 2224-2243.

Tokioka, T., K. Yamazaki, I. Yagai and A. Kitoh, 1984: A description of the Meteorological Research Institute atmospheric general circulation model (the MRI. GCM-I). Technical Reports of the Meteorological Research Institute, No. 13, 249pp.

, A. Kitoh, I. Yagai and K. Yamazaki, 1985 : A simulation of the tropospheric general circulation model. Part I: The January performancê. J. Meteor. Soc. Japan (submitted).

- - and A. Katayama, 1985: Atmospheric response to the sea surface temperature anomalies in the mature phase of El Niño under perpetual January condition. (to be submitted for publication).

Trenberth, K.E., 1984: Signal versus noise in the Southern Oscillation. Mon. Wea. Rev., 112, 326332.

Wagner, A. J., 1983: The climate of summer 1982 -A season with increasingly anomalous circulation over the equatorial Pacific Ocean. Mon. Wea. Rev., 111, 590-601.

Webster, P. J., 1981: Mechanisms determining the atmospheric response to sea surface temperature anomalies. J. Atmos. Sci., 38, 554-571-

\title{
1983 年初夏の海面水温異常に対する大気の応答：数値実験
}

\author{
時岡達志・山崎孝治・千葉＼cjkstart長 \\ 気象研究所予報研究部
}

気象研究所大気大循環モデル (MRI·GCM-I) を用いて，実测の海面水温異常 (SSTA) に対する大気の応答を 調べた。モデルは緯度 $4^{\circ}$ 経度 $5^{\circ}$ の分解能の 5 層対流圈モデルである。1982年から続いていたエル・ニーニョ が依然として強い勢力を保っていた1983年 5 〜 月を対象期間とした。

海面水温として1983年の実測值を用いたもの（ $\mathrm{R}$ と略記）と気候值を用いたもの（Nと略記）について，そ れぞれ 2 か月間数值樍分を行なった。RおよびNはそれぞれ初期時刻を 5 月 1 日 $00 Z$ から 3 日 $00 Z$ まで 12 時間 おきにとった 5 つの皘分から成り, SSTA に対する大気の応答 $(R-N)$ の有意性について統訃的検定を行 なった。

シミュレートされた月浐均值の差 $(\mathrm{R}-\mathrm{N})$ は低緯度のほとんどおよび中緯度の一部の領域で有意で，基本

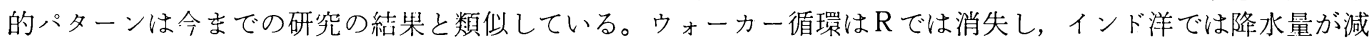
少する。対流圈上層では赤道をはさんで南北に対になった高気圧性循罟が偏差場（R一N）で見られ，亜熱帯 ジェットが強まる。中緯度では冬半球である南半球の応答の方が大きい。北半球ではいわゆる PNAに似たパ ターンがあらわれるが, SSTA の東偏に対応して冬の位置より東にずれている。

債分初期の傓差の発達としては，熱帯域では西進するロスビー波と東進するケルビル波の応答が顕著に見ら れる。また中緯度では，東部赤道太平洋に源をもつロスビー波の伝播が追跡される。 